\title{
Dysregulated signalling pathways in innate immune cells with cystic fibrosis mutations
}

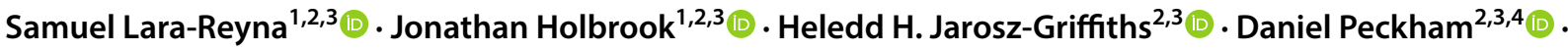 \\ Michael F. McDermott ${ }^{1,3}$ (1)
}

Received: 4 March 2020 / Revised: 22 April 2020 / Accepted: 24 April 2020 / Published online: 4 May 2020

(c) The Author(s) 2020

\begin{abstract}
Cystic fibrosis (CF) is one of the most common life-limiting recessive genetic disorders in Caucasians, caused by mutations in the cystic fibrosis transmembrane conductance regulator (CFTR). CF is a multi-organ disease that involves the lungs, pancreas, sweat glands, digestive and reproductive systems and several other tissues. This debilitating condition is associated with recurrent lower respiratory tract bacterial and viral infections, as well as inflammatory complications that may eventually lead to pulmonary failure. Immune cells play a crucial role in protecting the organs against opportunistic infections and also in the regulation of tissue homeostasis. Innate immune cells are generally affected by CFTR mutations in patients with CF, leading to dysregulation of several cellular signalling pathways that are in continuous use by these cells to elicit a proper immune response. There is substantial evidence to show that airway epithelial cells, neutrophils, monocytes and macrophages all contribute to the pathogenesis of CF, underlying the importance of the CFTR in innate immune responses. The goal of this review is to put into context the important role of the CFTR in different innate immune cells and how CFTR dysfunction contributes to the pathogenesis of $\mathrm{CF}$, highlighting several signalling pathways that may be dysregulated in cells with CFTR mutations.
\end{abstract}

Keywords Cystic fibrosis · Inflammation · Neutrophils $\cdot$ Monocytes $\cdot$ Macrophages $\cdot$ CFTR and autoinflammation

\section{Introduction: an overview of cystic fibrosis}

Cystic fibrosis (CF) is one of the most common life-threatening autosomal recessive genetic diseases in Caucasians, affecting approximately 48,000 individuals in Europe and 30,000 in the USA [1,2]. This condition is caused by mutations in the cystic fibrosis transmembrane conductance regulator (CFTR), which is a transmembrane ion channel highly

Samuel Lara-Reyna

umsjlr@leeds.ac.uk

$\triangle$ Michael F. McDermott

M.McDermott@leeds.ac.uk

1 Leeds Institute of Rheumatic and Musculoskeletal Medicine, University of Leeds, Leeds LS9 7TF, UK

2 Leeds Institute of Medical Research at St James's, University of Leeds, Leeds LS9 7TF, UK

3 Leeds Cystic Fibrosis Trust Strategic Research Centre, University of Leeds, Leeds LS9 7TF, UK

4 Adult Cystic Fibrosis Unit, St James's University Hospital, Leeds LS9 7TF, UK expressed by cells of the respiratory, digestive and male urogenital tracts [3-8]. Epithelial and secretory cells are known to be profoundly affected by CFTR mutations, due to altered physiological function as a result of abnormal production, maturation and function of the CFTR protein and aberrations in ion transport, most importantly chloride ions $\left(\mathrm{Cl}^{-}\right)$[9]. These changes result in a multisystem disease characterised by recurrent pulmonary infections, pancreatic insufficiency, gastrointestinal complications, CF-related diabetes, malnutrition, arthropathies and male infertility [10-17]. Until recently, treatments for $\mathrm{CF}$ were based on managing disease symptoms and complications rather than treating the underlying disease. Approximately 1 in 25 people in the UK is an asymptomatic carrier of a mutated CFTR gene and likewise 1 in 29 people in the USA.

Drugs used to treat CF frequently include pancreatic enzymes, mucolytics and, antibiotics, including low dose macrolides and other anti-inflammatory agents [18, 19]. The recent introduction of effective CFTR modulator therapy is revolutionising the management of CF. These drugs have variable efficacy and target the underlying problem by 
improving CFTR expression and function. Drug efficacy is variable with each drug or drug combination and they target specific CFTR class mutations; the drugs include Ivacaftor (VX-770), Lumacaftor (VX-809), Tezacaftor (VX-661) and Elexacaftor (VX-445). Ivacaftor is used to treat class III gating and residual function mutations (e.g. G551D, S549R and V250F), whereas the combination of Ivacaftor/Lumacaftor (Orkambi) and Ivacaftor/Tezacaftor (Symkevi) is effective for patients homozygous for $\Delta \mathrm{F} 508$ and those with one copy of $\Delta F 508$ as well as another residual function mutation [20, 21]. The recent approval of the triple-drug combination therapy, Ivacaftor/Tezacaftor/Elexacaftor (Trikafta) in the USA, heralds a paradigm shift in the treatment of CF, as this combination is highly efficacious for both patients who are homozygous and heterozygous for the $\Delta \mathrm{F} 508$ mutation $[20,21]$. The different types of class mutations, including the most common examples and the current individual treatments, for each type of class mutation, are summarised in Table 1.

Although initially, just a few studies highlighted the importance of the CFTR in the regulation of immune cell function, there is now more evidence to show the relevance of the CFTR expression in different cells of the immune system [22-30]. Several studies have revealed that specific cellular signalling pathways, of different immune cells with various CFTR mutations, are affected in CF [22-30]. Moreover, $\mathrm{CF}$ has been described as an autoinflammatory condition [28, 31], based on the abnormal inflammatory activity of innate immune cells, which is exacerbated by the atypical local tissue environment [27, 28]. Autoinflammatory conditions are primarily driven by aberrant activation of the innate immune system [32,33], which usually leads to abnormal production of pro-inflammatory cytokines such as TNF,
IL-1 $\beta$, IL-6, IL-17 and IL-18, whereby the local environmental factors may predispose the cells to an inflammatory phenotype [34, 35]. Autoimmune responses, in contrast, are directed against self-antigens and are characterised by the presence of autoreactive $\mathrm{T}$ cells and $\mathrm{B}$ cell-mediated autoantibodies [34]. Only a limited number of studies have reported the involvement of adaptive immune cells, such as $\mathrm{T}$ and $\mathrm{B}$ cells, affected by CFTR mutations in CF pathology [36-39]. Therefore, this review will explore existing reports in the literature detailing several mechanistic signalling pathways dysregulated in innate immune cells harbouring CFTR mutations.

\section{Cellular signalling pathways}

The cellular machinery is actively regulated by multiple complex signalling pathways, working together to maintain cellular fitness. Most of these pathways are functionally redundant, as a compensatory mechanism for reduced or absent activity of other similar pathways. For instance, different types of cellular death have been described in mammalian cells, including apoptosis (programmed cell death with chromatin condensation), necrosis (premature cellular death that causes membrane rupture and organelle release), pyroptosis (pro-inflammatory programmed cell death causing cellular destruction) and autophagic cell death (degradation of cellular components in an autophagic manner, leading to cellular death) [40]. All these mechanisms may result in a similar outcome; namely, cellular death; nevertheless, each mechanism accomplishes its primary function via different signalling pathways.

Table 1 CF class mutations and current therapies

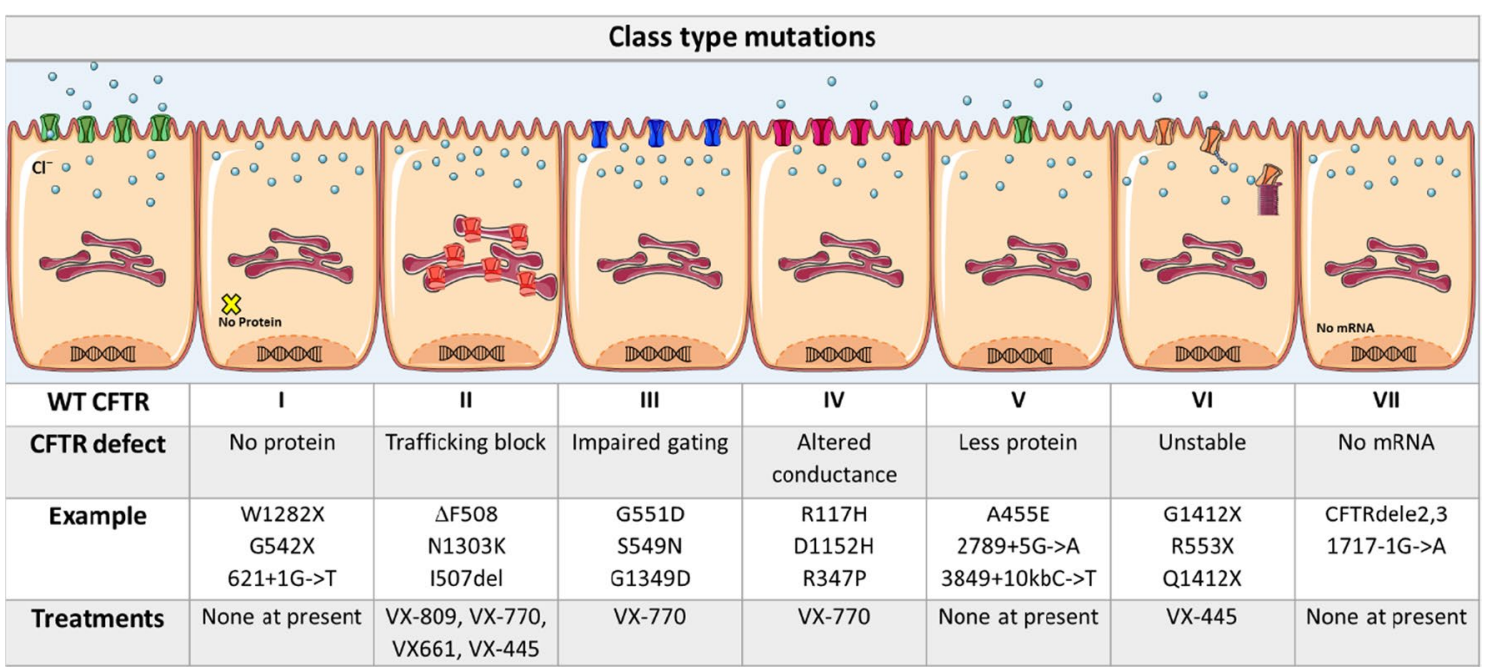

A summary of the seven different classes of CF mutations described above [214, 215]; alongside the most common examples and current treatments 
Cysteinyl aspartate-specific proteases, better known as caspases, are the most critical active enzymes involved in the execution of cellular apoptosis and pyroptosis [41, 42]. In terms of apoptotic cellular death, caspases can be divided into two leading families, initiator caspases $(-2$, $-8,-9,-10)$ and executioner caspases $(-3,-6,-7)$ [42]. Apoptosis can be induced by extrinsic cellular signals, e.g. TNF, or by intrinsic cytosolic insults, e.g. DNA damage, which eventually lead to cellular death [41, 42]. In contrast, pyroptotic cellular death frequently involves the formation of different inflammasomes, a critical mechanism in the induction of inflammation by innate immune cells [41, 43, 44]. Inflammasomes are cytosolic multiprotein complexes usually consisting of three main domains, the central sensory NOD-like receptor (NLR) domain, the adaptor protein apoptotic speck protein containing a caspase recruitment domain (ASC) domain and pro-caspase-1 domain [44, 45]. Several different inflammasomes have been described in mammalian cells, including AIM2, NLRC4, NLRP3 and NLRP1 $[44,45]$. When activated, all these inflammasomes direct the cleavage of pro-IL-1 $\beta$ and pro-IL-18 to their mature forms, IL-1 $\beta$ and IL-18. Similarly, to cellular death, the inflammasomes are also capable of reaching the same outcome; that is, the production of IL-1 $\beta$ and IL-18, via different signalling pathways. Some studies have reported overactivation of the NLRP3 inflammasomes in patients with CF, leading to excessive production of IL-1 $\beta$ and IL-18 [28, 46-48]; however, these various mechanisms are not the only redundant cellular pathways in mammalian cells. Many other mechanisms serve to induce alternative compensatory signalling pathways involving inflammation, metabolism, endoplasmic reticulum (ER) stress, ion transport and phagocytosis. For example, in $\mathrm{CF}$, the lack of complete CFTR functionality leads to reduced transport of $\mathrm{Cl}^{-}$into the extracellular space $[9,49]$. This ionic imbalance will lead to upregulation and overactivity of the epithelial sodium channel $(\mathrm{ENaC})$, resulting in sodium $\left(\mathrm{Na}^{+}\right)$influx into the cells, followed by water; thereby, causing dehydration of the airway surface liquid (ASL) layer in the lumen of the lungs [9, 28, 50, 51]. The mechanisms described above are not the only ones affected in $\mathrm{CF}$; therefore, the mechanistic signalling pathways altered in innate immune cells with CFTR mutations will be analysed in the following sections.

\section{Innate immune cells with CFTR mutations}

\section{Airway epithelial cells}

Airway epithelial cells (AECs) are the initial checkpoints in the defence against pathogens and other inhaled particulates, and these cells are crucial to the regulation of both innate and adaptive immune responses to these challenges $[52,53]$.
AECs are tailored with innate immune cell machinery such that they are able to detect pathogen-associated molecular pattern molecules (PAMPs) via a broad range of pattern recognition receptors (PRRs) [53-55]. The activation of PRRs (TLRs, NLRs, CLRs and RLRs) triggers intracellular signalling cascades that initiate pro-inflammatory, cytokine and chemokine release and antimicrobial responses [54-57]. In CFTR-deficient AECs, innate immune responses are intrinsically defective, resulting in altered pathogen interactions and immune cell communication. Several studies have described intrinsic upregulation of signalling pathways associated with pro-inflammatory cytokine transcription in $\mathrm{CF}$ epithelial cells [58-60]. Additionally, when CFTR-deficient AECs are exposed to Pseudomonas aeruginosa, there is activation of nuclear factor- $\kappa \mathrm{B}(\mathrm{NF}-\kappa \mathrm{B})$, which drives the expression of IL-8, a potent neutrophil chemoattractant $[61,62]$. Moreover, a recent report showed that elevated intracellular $\mathrm{Cl}^{-}$, resulting from defective CFTR ion transport, triggers pro-inflammatory cytokine secretion in $\mathrm{CF}$ epithelial cells through phosphorylation of the $\mathrm{Cl}^{-}$sensitive serum- and glucocorticoid-inducible protein kinase 1 (SGK1), with subsequent activation of the NF-kB pathway [63]. P. aeruginosa lipopolysaccharide (LPS) stimulation also increased intracellular $\mathrm{Cl}^{-}$levels, and triggered NF- $\mathrm{KB}$ activity in an SGK1-dependent manner, suggesting that alterations in intracellular $\mathrm{Cl}^{-}$may be a cause of both infection-dependent and -independent inflammatory responses [63]. Another study suggested that $\mathrm{Cl}^{-}$concentrations above $75 \mathrm{mM}$, in the IB3-1 CF epithelial cell line, can modulate IL- $1 \beta$ maturation, suggesting that $\mathrm{Cl}^{-}$itself can enhance inflammatory signalling in these cells [64]. Although, these studies demonstrate that the CFTR may be intrinsically proinflammatory, other reports have shown a high variability in AEC inflammatory responses $[39,65]$, with conflicting evidence found in vitro and in vivo studies [66-68]. It is important to mention that conflicting evidence may be due to differences in cell lines or the culturing conditions, and that all studies need to be analysed carefully.

While the central role of the CFTR channel is to balance the flux of $\mathrm{Cl}^{-}$and bicarbonate ions [69] to maintain a healthy ASL, several groups have proposed that the CFTR also influences the activity of various other ion channels, transporters and receptors [70], which may all contribute to the altered innate immune response seen in $\mathrm{CF}$ epithelial cells. Most notably, the CFTR has been shown to exert an inhibitory effect on $\mathrm{ENaC}[71,72]$. Human studies have indicated that variants in genes encoding $\mathrm{ENaC}$ chains can cause functional abnormalities, which result in CF-like symptoms, and that rare mutations causing reduced $\mathrm{ENaC}$ activity can slow disease progression in patients homozygous for CFTR $\Delta$ F508 mutation [73, 74]. Furthermore, ENaC $\beta$-chain expression was found to be upregulated in human bronchial epithelial cells (HBECs) with CF-associated 
mutations (IB3-1 and CuFi-1) and CF monocytes (with $\Delta$ F508/ $\Delta$ F508 mutations), leading to increased $\mathrm{Na}^{+}$influx and $\mathrm{K}^{+}$efflux. This ionic imbalance acts as a driving force for activation of the NLRP3-inflammasome [75-78]. In this study, an exaggerated pro-inflammatory response is seen in
CF cells when challenged with NLRP3-inflammasome activators LPS and ATP, leading to increased IL-18 secretion in CF HBECs, and IL-1 $\beta$ and IL-18 in CF monocytes (Fig. 1) [28]. This exaggerated inflammatory response was reduced when cells were pre-treated with small molecule inhibitors

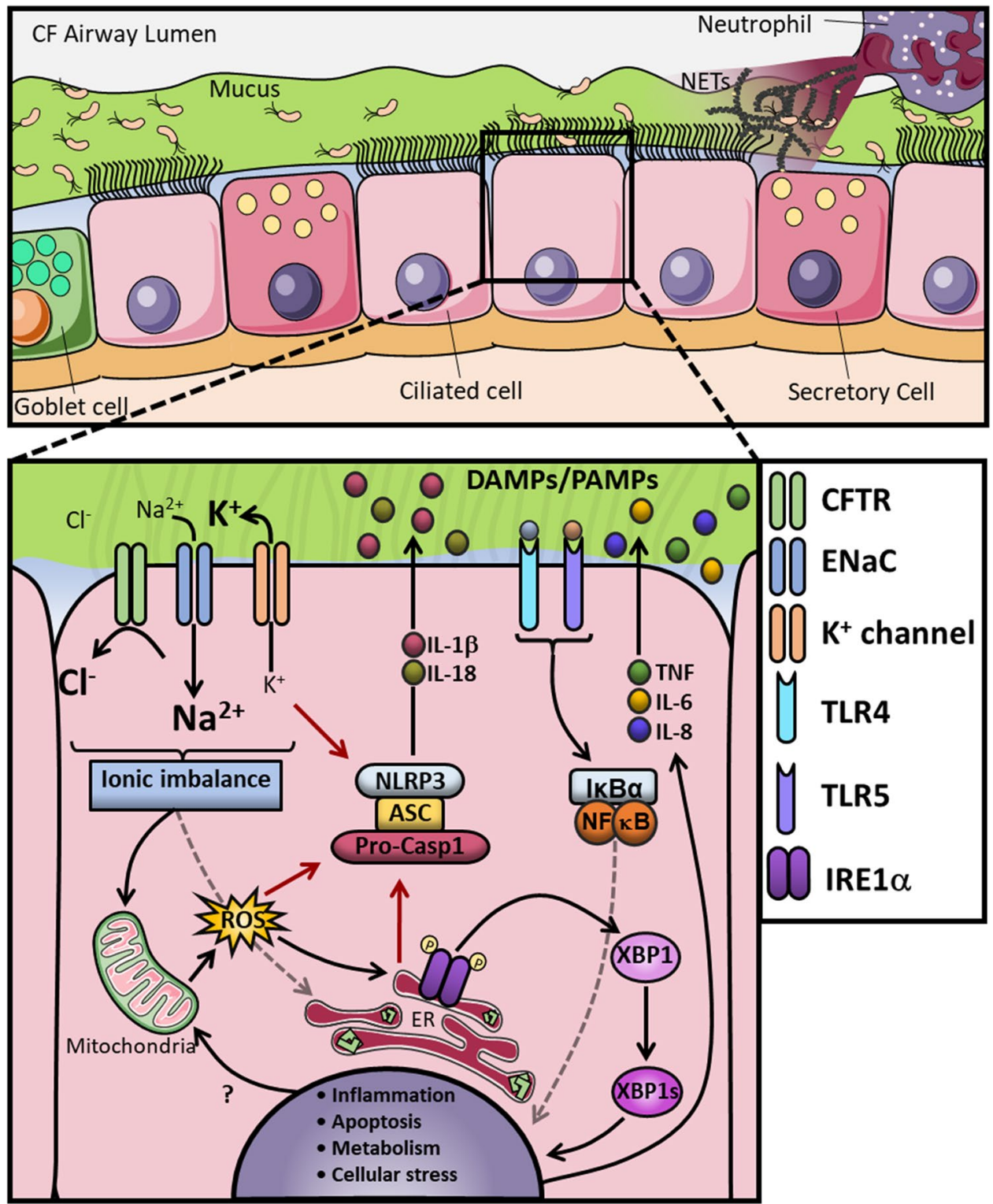

Fig. 1 CF airway and altered AECs mechanisms. a In this panel, a cross-section of the CF airways is represented, which showing the airway lumen on top and different epithelial cells on the bottom. In CF, the lack of CFTR function leads to increased $\mathrm{Na}^{+}$influx by $\mathrm{ENaC}$, followed by water absorption leading to dehydration of the periciliary layer (PCL), with accumulation of a thick, dense mucus in the apical surface and persistent colonisation by opportunistic pathogens. The chronic inflammatory microenvironment in the lung facilitates neutrophilic infiltration, with subsequent release of excessive amounts of neutrophil extracellular traps (NETs) upon activation. b In CF AECs the CFTR malfunction decompensates the intracellular ionic balance, leading to overactivity of $\mathrm{ENaC}$ and increased $\mathrm{Na}^{+}$influx and $\mathrm{K}^{+}$ efflux, as a consequence. This exaggerated $\mathrm{K}^{+}$efflux, combined with increased ER stress and reactive oxygen species (ROS) production, activates the NLRP3 inflammasome and further increases IL-1 $\beta$ and IL-18 secretion. The ionic imbalance is also associated with increased ER stress, ROS and metabolic turnover. The misfolded CFTR, combined with the ionic imbalance, causes IRE1 $\alpha$ activation with the generation of the spliced form of XBP1 (XBP1s), which, in turn, activates a number of UPR-related genes inducing inflammation. The overstimulation of both surface and intracellular receptors, through DMAPs and PAMPs, combined with all the other dysfunctional signalling pathways, causes an exacerbated inflammatory response with increased production of TNF, IL-6 and IL-8 
of NLRP3 and ENaC; thereby, uncovering a molecular link between enhanced $\mathrm{ENaC}$-dependent $\mathrm{Na}^{+}$influx, $\mathrm{K}^{+}$efflux and NLRP3-inflammatory cytokine production [28].

Under normal conditions, the transport of $\mathrm{Cl}^{-}$ions is coupled to an increase in $\mathrm{K}^{+}$conductance, in order to maintain the driving force for anion movement across the membrane [79]. The KCa3.1 calcium-activated potassium channel, encoded by the Kcnn 4 gene, is essential in calcium-activated intestinal anion secretion [80,81], and physically interacts with CFTR in the apical membrane of airway epithelial cells [82]. KCa3.1 and CFTR co-localise at the plasma membrane with aggregation of $\mathrm{KCa} 3.1$ channels, leading to an enhanced interaction with CFTR channels, following an increase in intracellular calcium $\left(\mathrm{Ca}^{2+}\right)$ concentration [79]. The Kcnn4 gene has been suggested as a putative modifier of CF severity in humans [83], and it was thought that increased activity of $\mathrm{KCa} 3.1$ might aid in counterbalancing the failure of anion and fluid secretion in intestinal epithelial cells. In a recent study, a double mutant mouse ( $\mathrm{Cftr}^{\Delta \mathrm{F} 508 / \Delta \mathrm{F} 508}$ and $\left.\mathrm{Kcnn}^{-/-}\right)$showed improved survival without alteration in the intestinal secretory function, when compared with the $\mathrm{Cftr}^{\Delta \mathrm{F} 508 / \Delta \mathrm{F} 508}$ mouse [83]. Interestingly, it was found that inhibiting the KCa3.1 channel, in the $\mathrm{Cftr}^{\triangle \mathrm{F} 508 / \Delta \mathrm{F} 508}$ mice, reduced lethality and decreased the level of circulating TNF [83]. It would be interesting to explore whether NLRP3-inflammasome activation, IL-1 $\beta$ and IL-18 are also reduced with KCa3.1 channel inhibition. Expanding on this, Phillip et al. explored Th2 responses and found that silencing the STAT6 regulator of the Th2-driven immune response significantly reduced lethality in the CF animals [84]. This supports evidence from studies in macrophages, whereby an imbalance in polarisation towards the M1 pro-inflammatory phenotype suggests a defect in the STAT6 pathways, and interestingly, inhibition of the KCa3.1 channels reduces M1 polarisation [85]; however, the macrophage imbalance is likely to be a combination of several factors as it will be discussed in the macrophage section [86]

Another channel that is altered in $\mathrm{CF}$ is the $\mathrm{Ca}^{2+}$ releaseactivated $\mathrm{Ca}^{2+}$ channel, ORAI1. Balghi and colleagues found a twofold elevation in the expression of ORAI1 in the cell membrane of Cftr-deficient ACEs [87]. They also reported a twofold increase in total intracellular $\mathrm{Ca}^{2+}$ and iCRAC current and a corresponding twofold increase in IL-8 secretion. This increase in $\mathrm{Ca}^{2+}$ is likely to trigger the conductance of the $\mathrm{KCa} 3.1$ channel and enhance inflammatory signalling, as described above. It has been suggested that the $\mathrm{KCa} 3.1$ channel is controlled by $\mathrm{Ca}^{2+}$ microdomains, and that $\mathrm{KCa} 3.1$ and Orai1 form part of a macromolecular complex organised by PDZ-containing scaffolding proteins [88].

TMEM16A (anoctamin 1) is a non-CFTR $\mathrm{Cl}^{-}$channel which is also activated by $\mathrm{Ca}^{2+}$. A recent study by Benedetto et al. found that TMEM16A is not only essential for $\mathrm{Ca}^{2+}$ activated chloride currents in both mouse intestine and airways, but it is also essential for the correct activation and membrane expression of CFTR, suggesting an overlap in CFTR- and $\mathrm{Ca}^{2+}$ - dependent chloride transport [89]. Comparable to KCa3.1 and Orai1, TMEM16A also interacts with CFTR via PDZ-domain proteins [89]. Considering the increased levels of $\mathrm{Ca}^{2+}$ in CF AECs and subsequent increased expression of ORAI1, ensuing upregulation of TMEM16A could also be expected; nevertheless, a study on cultured HBECs reported no differences in the expression of TMEM16A between CF and non-CF cells [90]. When CF AECs are exposed to pyocyanin (a major virulence factor of $P$. aeruginosa), the expression of TMEM16A and mucin $5 \mathrm{AC}$ is increased, causing mucus hypersecretion [90]. While under normal conditions, TMEM16A supports $\mathrm{Cl}^{-}$conductance and fluid secretion in ciliated AECs, during inflammation TMEM16A expression is upregulated, primarily in mucus-producing goblet cells, leading to excessive mucus secretion, with little expression induced in the ciliated epithelial cells that express CFTR [89]. Kunzelmann et al. suggest that, in the absence of bacterial infections, intrinsic inflammation could be caused by delocalisation/dysfunction of CFTR, followed by upregulation of TMEM16A (possibly as a result of increased intracellular $\mathrm{Ca}^{2+}$ ), particularly in mucus-secreting cells thereby contributing to CF pathogenesis [91]. Another study reported that the overexpression and induction of TMEM16A attenuate the production of proinflammatory cytokines, IL-6, IL-8, CXCL1-3 and CCL2 in CF HBECs in air-liquid culture; however, the mechanism of action remains elusive [92]. It seems that augmenting mucus secretion through activation of TMEM16A would over-ride this phenomenon resulting in increased pro-inflammatory cytokine production, as a consequence of increased mucus build-up and bacterial colonisation. Potentially, a more direct approach to TMEM16A activation could be to specifically target ciliated AECs and activate TMEM16A allosterically without triggering $\mathrm{Ca}^{2+}$ signalling, which would induce pro-inflammatory cytokine secretion [93]. Alongside CFTRmediated ion channel disturbance in $\mathrm{CF}$, a number of studies have reported dysregulated or excessive apoptosis in $\mathrm{CF}$ epithelial cells following external stimuli [61,94]; a recent report shows that, under basal conditions, Fas expression was increased in epithelial cell lines leading to increased activation of caspases- 3 and -8 and subsequent apoptosis. Interestingly, treatment of primary non-CF bronchial epithelial cells with a CFTR inhibitor resulted in increased Fas expression, suggesting a link between CFTR function and Fas expression [95].

The CFTR receptor itself also has a direct role in the clearance of pathogens which enter the lung. When exposed to infection, the CFTR protein acts as a receptor for $P$. aeruginosa in AECs, and it is thought to be involved in uptake and clearance of this pathogen [96, 97]. P. aeruginosa also induces gene expression via activation of TLRs. CF AECs 
exposed to this pathogen release excessive amounts of proinflammatory cytokines, mainly mediated by TLR4/LPS and by TLR5/flagellin interactions $[98,99]$. Dysregulation of intracellular TLR4 trafficking has also been noted in human CF AECs as compared to non-CF controls [100-102]. Epithelial cells lacking CFTR also have impaired uptake and breakdown of conidia, which is released from Aspergillus fumigatus spores [103]. The soluble pattern recognition receptor, pentraxin 3 (PTX3), is secreted by a variety of immune cells including AEC [104], in response to conidia and is involved in the recognition, uptake and killing of conidia [105]. Furthermore, neutrophil elastases and $A$. fumigatus proteases were found to be responsible for the degradation of the conidial recognition site at the N-terminus of PTX3, contributing to inefficient fungal clearance in CF [106, 107]. Recent human studies, using the CFTR modulator Ivacaftor, found a decreased occurrence of $A$. fumigatus in sputum cultures in CF patients with a G551D mutation; however, the mechanism remains undetermined [108]. Collectively, these studies suggest that loss of functional CFTR and the compound effects of ionic imbalance could prime the innate immune system in advance of infection, leading to heightened inflammatory responses and proapoptotic priming when an infection is present (Fig. 1).

\section{Neutrophils}

Neutrophils are commonly considered to be the first line of defence against infection and whilst they are the most abundant circulating leukocyte in human blood, constituting about $60 \%$ of white blood cells, the number of neutrophils present in the pulmonary capillaries is increased in CF [109, 110]. Upon interaction with a broad range of pathogens, pro-inflammatory cytokines or other inflammatory signals, neutrophils become activated and move towards the site of inflammation, where they mobilise to clear the invading organism through phagocytosis [111-113], with the release of neutrophil extracellular traps (NETs) [114, 115], as well as cytokines and chemokines [116, 117]. Neutrophils are key inflammatory cells in the immune system's arsenal, and the dysregulation of approximately 90 of their genes related to the production of cytokines, chemokines, interleukin receptors, colony-stimulating factors and intracellular signalling molecules dramatically contributes to the inflammatory phenotype found in CF [118]. This dysregulation may also lead to an increased risk of infection taking place in the lungs by P. aeruginosa [119, 120], Staphylococcus aureus [121] and Burkholderia cepacia complex [122].

The CFTR has been shown to be expressed on the cellular surface of neutrophils, indicating that their dysregulation is primarily caused by the absence of a functioning CFTR protein, as opposed to just being a secondary effect of mutated CFTR in epithelial cells [123]. Typically, the CFTR is recruited to phagosomes in neutrophils, assisting in the killing of phagocytosed pathogens by moving $\mathrm{Cl}^{-}$ions into the phagolysosome to produce hypochlorous acid $(\mathrm{HOCl})$ $[124,125]$; however, in neutrophils with CF mutations, the dysfunctional CFTR compromises the ability of neutrophils to kill pathogens due to defective $\mathrm{HOCl}$ production in these compartments [124, 126, 127]. Although another study was unable to find impaired phagocytosis of $P$. aeruginosa in neutrophils with CF mutations, they did find that phagocytosis is impaired in monocytes from patients with CF [128]. The treatment of CF patients, carrying at least one copy of the G551D mutation, with Ivacaftor leads to reduced migration and activation of neutrophils [129], as well as improved bacterial clearance in this cohort of patients [127]. Another potential therapeutic target for $\mathrm{CF}$ was proposed to be histone deacetylase 6 (HDAC6), as its depletion, in a mouse model, reduced the recruitment of neutrophils to the lungs, followed by an improved response to infection and an increased rate of bacterial clearance and reduced weight loss [130].

Neutrophils have the ability to expel both their nuclear and mitochondrial DNA coated with antimicrobial granular proteins, such as neutrophil elastase (NE) and myeloperoxidase (MPO), into the extracellular space in net-like structures called NETs, which are used to enmesh pathogenic microorganisms, thereby aiding in their clearance [131]. Before the discovery of NETosis (controlled neutrophil cell death with the release of NETs), necrosis was generally considered to be the primary source of neutrophil DNA in the lungs of patients with CF; however, this was subsequently revealed not to be the case, as NETosis was shown to be responsible for the release of myeloperoxidase (MPO), heparin-binding protein (HBP), DNA and NE in CF sputum and bronchoalveolar lavage fluid (BALF) [132-135]. As the high concentration of inflammatory markers and these proteins, both in the CF sputum and BALF, correlates with decreasing lung function, NETosis plays an essential role in the pathogenesis of CF [132, 134, 136-146]. The raised levels of NE and cathepsin G have been suggested to be responsible for increased levels of peptides and amino acids in sputum samples, whilst the raised concentrations of these peptides and amino acids correlate with increased frequency of $P$. aeruginosa infection in the lungs of patients with CF [147]. The dysregulation of NETosis plays a prominent role in CF as well as other autoinflammatory diseases, as the DNA from these NETs exacerbates the dehydration of mucus, resulting in further airway clogging, thereby producing, as a consequence, an environment which is prone to bacterial infections [131, 148]. Unrestricted NE activity, in 3-month-old infants with $\mathrm{CF}$, has been associated with the development of bronchiectasis, adding to the evidence that respiratory 
infections in CF lead to neutrophilic infiltration, inflammation and ultimately to a declining respiratory function $[149,150]$; nevertheless, a recent study found no association between inflammation, abnormal physiology and structural changes in one-year-old infants, contradicting previous reports [151].

The recent observation of autoantibodies against components of NETs, in patients with CF, has been correlated with declining lung function and provides an insight into the development of autoimmunity in CF $[152,153]$. Impaired degranulation, due to decreased Rab27a activity and delayed neutrophil apoptosis, leads to an excessive NET formation in the lungs of patients with $\mathrm{CF}$, and these defects are reversed by Ivacaftor therapy in patients with G551D mutations $[154,155]$. Some of the current therapies, such as the use of DNase, to help clear the viscous mucus in the lungs of patients with $\mathrm{CF}$, may exacerbate $\mathrm{NE}$ activity, while the use of protease inhibitors has been shown not to affect CF sputum [156]. Recently the exhaled breath condensate (EBC) test was investigated to establish whether there was a link between inflammatory markers in the EBC and clinical outcome. NE was the only inflammatory marker found to be raised in EBC; conversely, this did not correlate with clinical outcome in these patients [157]. As, it has been reported that NE directly targets the CFTR interfering with its functionality [158], studies have aimed to inhibit NE and establish why previous NE inhibition studies have had mixed results $[159,160]$. In CF, micro RNA (miRNA) miR-636 was found be upregulated in neutrophils, and has been suggested to play an essential role in the chronic inflammation seen in CF by decreasing the expression of IL1R1 and IKK $\beta$ proteins, as well as increasing the expression of RANK [161]. Increased expression of the chemokine receptor, CXCR4, was found on neutrophils with CF mutations [162]; moreover, these raised levels in CXCR4 were associated with chronic fungal infection by Aspergillus fumigatus in patients with CF [163]. The cleavage of another chemokine receptor, CXCR1, has also been linked to impaired bacterial clearance in CF [164]. Other pro-inflammatory signals, such as ROS [165] and colony-stimulating factors [166], are significantly raised in CF; likewise, levels of the bioactive fragment of collagen called proline-glycine-proline (PGP) which is generated by the activity of both prolylendopeptidase and matrix metalloproteinase-9 (MMP9), are also raised [167]. As PGP acts as a stimulant of neutrophil migration into tissues, as well as inducing epithelial remodelling, it has been suggested that the raised levels of PGP found in the lungs of children with CF may exacerbate the inflammatory phenotype found in these patients [167]. The implications of the CFTR in neutrophil activity are more than clear and perhaps these new insights can help to achieve better understanding of these myeloid cells in the pathogenesis of CF.

\section{Monocytes}

Monocytes are central circulating white blood cells originating from the bone marrow with the potential to be differentiated into macrophages and dendritic cells, which are professional antigen-presenting cells (APC) involved in the interaction with the adaptive immune system. The CFTR plays a vital role in myeloid cells, and it has been shown that in conditional KO mice models, where only myeloidderived cells lack CFTR expression, the absence of the CFTR was directly involved in cell function [168]. Under normal conditions, these myeloid CFTR KO mice did not show any visible phenotypical alterations as compared to their WT counterparts; interestingly, when the lungs of these mice were exposed to bacterial pathogens, the rodents displayed significantly higher amounts of inflammatory cytokines and a decreased survival rate as compared to WT mice [168]. Although this study did not directly associate monocytes with the atypical response to bacteria in these mice, other studies have shown the importance of the CFTR in the regulation of monocyte function [24, 25, 27, 169]. The expression of the surface markers CD14 and HLA-DR was shown to be downregulated in monocytes from children with CF, alongside with deficient phagocytosis [170]. Later reports showed no differences in the monocyte classical $\left(\mathrm{CD} 14^{++} \mathrm{CD} 16^{-}\right)$, intermediate $\left(\mathrm{CD} 14^{+} \mathrm{CD} 16^{+}\right)$, or non-classical $\left(\mathrm{CD} 14^{+} \mathrm{CD} 16^{++}\right)$subpopulations $[25,171]$; however, expression of M-CSF, TLR4, IL-4R $\alpha$, IL-13R $\alpha$, TIMP-1 and Cox-2, were shown to be upregulated in monocytes from $\mathrm{CF}$ patients, demonstrating that CFTR mutations intrinsically affect these myeloid cells [25]. TLR4, in particular, has been consistently reported to be upregulated in both monocytes and macrophages from patients with $\mathrm{CF}$ and these increased levels of TLR4 were not related to pulmonary infections $[24,25,102]$. This persistent TLR4 upregulation might be linked to the exaggerated inflammatory response seen in patients with CF. Freshly isolated monocytes from patients with $\mathrm{CF}$ did not show any differences in the surface marker expression of CD68 and CD80, but significantly higher expression of CD163 and CD206 was observed when compared with HC monocytes [172]; however, the monocytes of two different patient cohorts, on Ivacaftor and Ivacaftor/Lumacaftor, showed normalisation of the increased levels of CD163 and CD206, which were comparable to the levels of HC monocytes [172]. The surface markers CD68 and CD80 are associated with a proinflammatory phenotype, while the CD163 and CD206 are linked to an anti-inflammatory phenotype, suggesting that there is a persistent and non-resolving inflammatory 
response in $\mathrm{CF}$ [172]. These studies provide more evidence that monocytes with $\mathrm{CF}$ mutations show phenotypic alternations that can be improved with the administration of CFTR modulators. In a different study, IL-8 was shown to be abnormally increased in CF monocytes after LPS challenge; however, these higher levels of IL-8 were not associated with TLR4 overexpression but, instead, with an increase in the MAPK signalling pathway [169]. In another study, it was shown that the monocytes from patients with $\mathrm{CF}$, with at least one copy of the G551D mutation, treated for seven days with Ivacaftor displayed a reduction in IFN $\gamma$ induced related inflammatory proteins [173]. Similarly, Velard et al. found that the percentage of double positive monocytes, $\mathrm{RANK}^{+}$and M-CSFR ${ }^{+}$, was strongly increased $(\sim 91 \%)$ in CF patients bearing at least one G551D copy when compared with HC [174]; interestingly, this increased percentage in $\mathrm{RANK}^{+}$and $\mathrm{M}-\mathrm{CSFR}^{+}$monocytes, was significantly decreased after 9 and 12 months of treatment with Ivacaftor [174]. It is of great interest to investigate how this increased expression in M-CSFR is involved in the differentiation process of monocytes towards macrophages and dendritic cells in patients with $\mathrm{CF}$.

Monocytes with CFTR mutations show an exaggerated inflammatory phenotype when stimulated with LPS and ATP, and this activation state was NLRP3 dependent [28]. Monocytes from patients with CF showed increased production of IL- $1 \beta$ and IL-18, which was associated with higher activity of caspase- 1 and raised extracellular ASCs [28]; interestingly, inhibition of $\mathrm{ENaC}$ decreased the exacerbated secretion IL- $1 \beta$ and IL-18 only in monocytes with CF mutations, while this inhibitory effect was not seen in monocytes from patients with other inflammatory conditions [28]. Furthermore, the increased levels of IL-1 $\beta$ and IL-18 were also detected in the sera of patients with CF [28], indicating an essential role of these two cytokines in the pathogenesis of this disease, further supporting the autoinflammatory phenotype seen in patients with $\mathrm{CF}[31,175$, 176]. Moreover, the CFTR modulators Ivacaftor/Lumacaftor and Ivacaftor/Tezacaftor showed a powerful anti-inflammatory effect in patients with CF, reducing the levels of IL-18, and both IL- $1 \beta$ and IL-18, correspondingly, in monocytes and serum of patients with CF [177]. An altered X-linked miRNA profile has been shown in $\mathrm{CD} 14^{+}$monocytes from patients with CF [178]. In this study, the authors found that several X-linked miRNAs were significantly upregulated in CF monocytes, with miR-224-5p being the most prominent; furthermore, SMAD family member 4 (SMAD4), a validated target of miR-224-5p was found to be downregulated in the CF monocytes [178]. The full implications of miRNAs in monocytes with CF mutations are still unknown, but these inhibitory miRNAs are indeed implicated in the pathogenesis of CF [179]. In a different study, transcriptomic RNA sequencing (RNAseq) was carried out in whole blood from patients with $\mathrm{CF}$, and 491 genes were found to be differentially expressed as compared to non-CF controls, with further validation of the most overexpressed genes, MMP9 and SOCS3 by qPCR [180]. It has been shown that monocytes from patients with $\mathrm{CF}$ have increased expression of MMP9, associated with increased intracellular $\mathrm{Ca}^{2+}$ when compared with non-CF monocytes [180, 181]; remarkably, monocytes with from CF patients treated with Ivacaftor/ Lumacaftor showed reduced intracellular $\mathrm{Ca}^{2+}$ levels [180]. Finally, a recent study showed that overexpression of PD-L1 in monocytes with CF mutations, was associated with $P$. aeruginosa infections in patients with CF [182]; furthermore, not only PD-L1 was increased in the CF monocytes, but also the levels of SPD-L1 were increased in the plasma of these patients, as well as PD- 1 in both $\mathrm{CD} 4^{+}$and $\mathrm{CD} 8^{+}$ $\mathrm{T}$ cells [182]. Clearly, several distinct mechanistic pathways are dysregulated in monocytes with CF mutations, and a better understanding of all these mechanisms is needed.

\section{Macrophages}

As already described, inflammation is a common complication in CF. Although epithelial cells, neutrophils and monocytes play an essential role in the pathogenies of $\mathrm{CF}$, macrophages are largely responsible for the initiation and resolution of the inflammatory response [183-185]. During inflammation, monocytes are recruited to the affected site and these myeloid cells can then be differentiated and subsequently polarised into classically activated macrophages or alternatively activated macrophages, better known as pro-inflammatory (M1) and anti-inflammatory (M2), respectively [186]. Although distinct molecular signalling pathways in monocyte-derived macrophages (MDMs) are known to be affected by CFTR mutations [26, 27, 154, 172, 187], it is important to mention that other types of macrophages exist, known as tissue-resident macrophages, which are also affected by these types of mutations [30, 188, 189]. The proportion of macrophages is typically elevated in the airways, both in patients with CF and mice with CFTR mutations [86, 190, 191]. Furthermore, M1 and M2 macrophages are reported to be increased in the lung and peritoneum of mice with CFTR mutations [86]. Deficient polarisation of M2 MDMs has been reported in human macrophages, with significantly lower production of IL-10 and absence of expression of IL-13R $\alpha 1$, while no difference was observed in the proportion of M1 MDMs [26, 27]. While no proportional differences were found in M1 MDMs with CFTR mutations, there is substantial evidence to show that these cells consistently secrete excessive amounts of pro-inflammatory cytokines, including TNF, IL-1 $\beta$, IL-6, IL-8 and IL-12, under basal conditions, and also after stimulation (Fig. 2) $[27,154,172,189,192]$. Furthermore, the upregulation of 


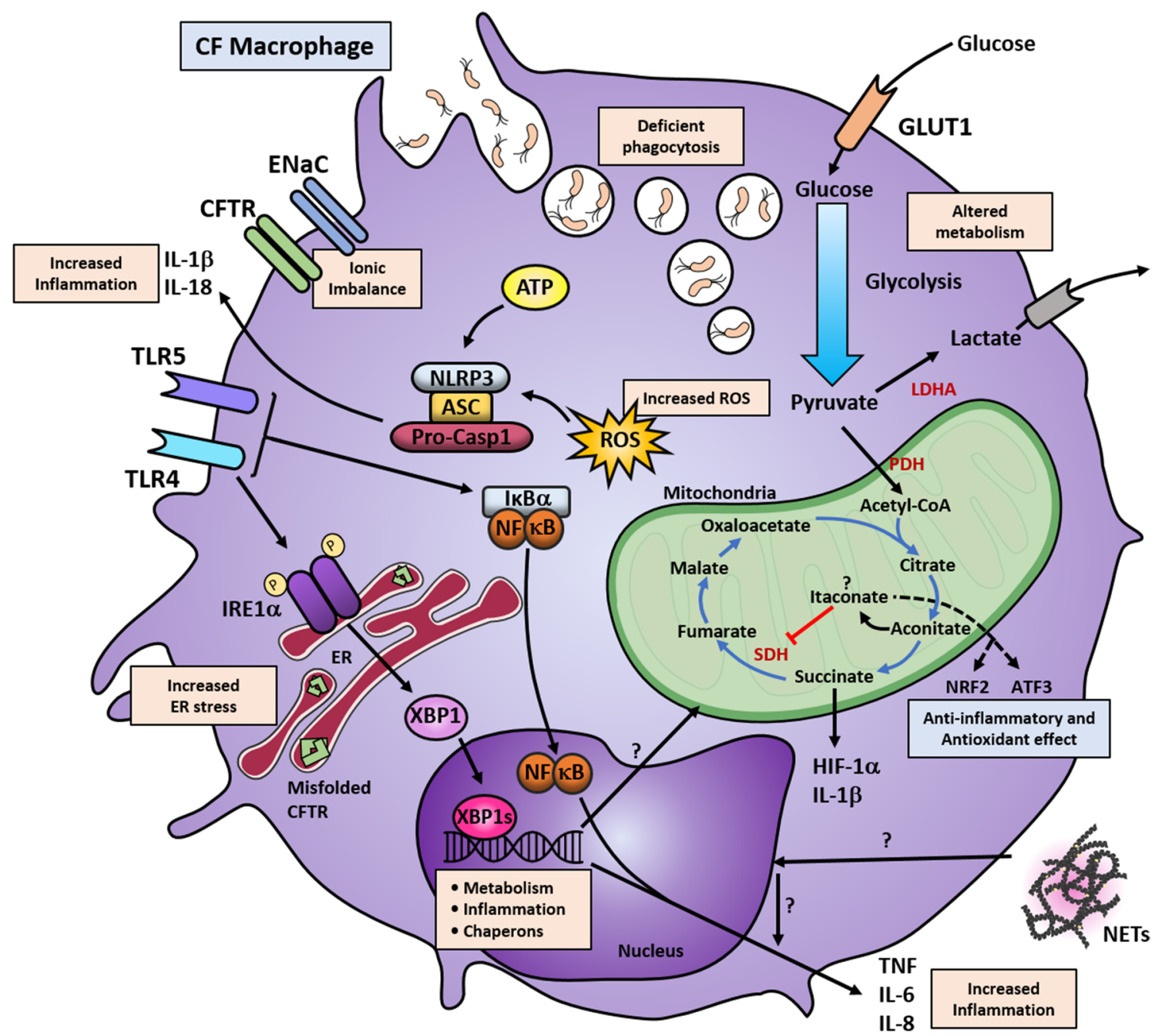

Fig. 2 Altered signalling pathways in CF macrophages. Macrophages with CFTR mutations show alterations in multiple cellular pathways. The mutated CFTR causes ionic imbalance, with accumulation of misfolded protein in the case of the $\Delta \mathrm{F} 508$ mutations and primes these myeloid cells towards an altered immune response or chronically activating other signalling pathways. CFTR malfunction primes the overactivation of $\mathrm{ENaC}$, leading to increased $\mathrm{Na}^{+}$influx, which is then compensated by $\mathrm{K}^{+}$efflux. The increased $\mathrm{K}^{+}$efflux, combined with increased ROS and ATP production, activates the NLRP3 inflammasome with further increased IL- $1 \beta$ and IL-18 secretion. CF macrophages have raised levels of TLR4 expression, and the resultant overactivation of NF- $\mathrm{KB}$ leads to increased TNF and IL- 6 production. Induction TNF and IL-8 may also occur through NETs by an unknown mechanism. Similarly, chronic TLR4 activation, possibly due to the persistent bacterial colonisation in the lungs, leads to the overactivation of IRE1 $\alpha$; thereby, triggering XBP1s. This production of XBP1s induces transcriptional activation of several UPR responsive genes involving metabolism, inflammation and protein folding. XBP1s overexpression induces a low-grade chronic induction of IL-6 and TNF, which exacerbates the inflammatory response when com-

the transcription factor XBP1s has been reported in lung tissue-resident macrophages and M1 MDM from patients with $\mathrm{CF}$, in association with excessive production of IL-6 bined with other signalling pathways. XBP1s also regulate metabolic pathways and, in CF macrophages, the increased metabolic state can be reduced by IRE1 $\alpha$ inhibition. Macrophages with CFTR mutations also show increased glycolytic flux and mitochondrial respiration. It is known that in M1 macrophages the Krebs cycle favours the accumulation of succinate and citrate. Succinate accumulation leads to stabilisation of HIF- $1 \alpha$, which can induce IL- $1 \beta$ production and activation of glycolytic genes. It may be possible that in $\mathrm{CF}$ macrophages, this axis is favouring a proinflammatory response and increased glycolytic function. Alternatively, citrate is converted into aconitate, facilitating the synthesis of itaconate, which is a potent anti-inflammatory metabolite; however, the role of itaconate in $\mathrm{CF}$ is unknown. CF macrophages also display deficient bacterial killing with intracellular accumulation of phagocytic vesicles. Altogether, these mechanisms influence the altered innate response elicited by macrophages. LDHA lactate dehydrogenase A, GLUT glucose transporter, $S D H$ succinate dehydrogenase, $P D H$ pyruvate dehydrogenase, $E R$ endoplasmic reticulum, $H I F-1 \alpha$ hypoxia inducible factor 1 subunit alpha, NRF2 nuclear factor erythroid-2-related factor 2, ATF3 activating transcription factor $3, \operatorname{ROS}$ reactive oxygen species

and TNF [27, 30, 189]. Moreover, a hypermetabolic state has been reported in M1 MDMs from patients with CF, showing higher glycolytic and mitochondrial activity associated 
with increased activity of the IRE $1 \alpha$-XBP1 signalling pathway [27]. Interestingly, it has been previously hypothesised that the chronically raised levels of pro-inflammatory cytokines might result in metabolic disturbances during the pathogenesis of CF [193, 194]. Certainly, this is the case in other immune conditions, where the excessive levels of pro-inflammatory cytokines, as well as other intrinsic cellular abnormalities, contribute to the induction of cellular stress, which is directly associated with disruption of cellular metabolism [195-198]. It would be interesting to investigate the effects of the increased levels of pro-inflammatory cytokines, present in patients with $\mathrm{CF}$, concerning glycolytic and mitochondrial metabolism.

Exaggerated inflammatory and metabolic responses are not the only altered pathways in macrophages harbouring CFTR mutations. It has been reported that such macrophages display increased apoptosis and deficient bacterial killing, associated with decreased phagocytic capacity (Fig. 2) [172, 199, 200]. MDMs with CFTR mutations showed a $40 \%$ reduction in phagocytosis, which could be recovered under the administration of Ivacaftor, but not Ivacaftor/Lumacaftor; this recovery was associated with a significant increase in the killing of the opportunistic pathogen $P$. aeruginosa, by CF MDMs treated with Ivacaftor [172]. The deficient phagocytic response towards $P$. aeruginosa by CF macrophages, might be due to the lower expression in TLR5, as this is the preferred receptor used by macrophages to detect this pathogen [201]. As discussed already, NETs are increased in the lungs of patients with $\mathrm{CF}$ and, interestingly, the production of NETs in response to $P$. aeruginosa infections is influenced by macrophage migration-inhibitory factor (MIF), via induction of mitogen-activated protein kinase [135]. In a different study, Gray et al. reported that NETs could also induce the production of TNF and IL-8 in human MDMs, with significantly increased levels of these two cytokines in CF MDMs (Fig. 2) [154].

Macrophages are undoubtedly dysfunctional or overactive in patients with CF, showing excessive amounts of proinflammatory cytokine production, altered polarisation ratios with reduced numbers of M2 MDMs, increased metabolic rates, as well as deficient phagocytosis and killing properties. It would be interesting to elucidate whether these macrophage dysfunctions are due to intrinsic or extrinsic influences, or indeed a combination of both. Recently, itaconate has been described as a potent anti-inflammatory metabolite implicated in metabolic reprogramming during macrophage activation [202-204]. When macrophages become activated, aconitate is converted to itaconate in the Krebs cycle, and it is known that itaconate acts as an anti-inflammatory molecule, similar to IL-10 [202-204]. Further investigation of whether itaconate and other metabolites are dysregulated in macrophages with CFTR mutations is in progress. As the triple-drug combination therapy, Trikafta, has been recently approved in the US, it will be of particular relevance to investigate the effects of this drug combination on macrophages with CFTR mutations. Altogether, it is clear that the CFTR plays a significant role in the regulation of several mechanisms in macrophages, and a dysfunctional CFTR can lead to several cellular abnormities in these phagocytic cells.

\section{Fibroblasts}

Fibroblasts are essential stromal cells that are involved in the regulation of the tissue environment, wound healing, angiogenesis and tissue fibrosis. Recently, several studies have demonstrated that these cells are essential in the regulation of the inflammatory response and that they play a crucial role in the pathogenesis of several immune-related disorders [205, 206]. Although there is limited information about fibroblasts in CF, it is known that the CFTR is expressed in fibroblasts [193, 207, 208]. Early studies have shown that CF fibroblasts display an altered glycolytic metabolism, with increased activity of glycolytic enzymes [193]. Moreover, lung fibroblasts with CFTR mutations are overresponsive when stimulated with LPS, secreting excessive amounts of TNF, IL- $1 \beta$ and IL- 6 , when compared with WT fibroblasts [208]. All this is in line with the reports showing increased inflammatory markers in the lungs of patients with CF. It would be of great interest to further investigate whether the chronic activation of fibroblasts in $\mathrm{CF}$, due to the long-lasting inflammation in the lungs, is associated with the decline in respiratory function over time. Moreover, it would be of great interest to explore the effect of the CFTR modulators on these stromal cells. Further investigations should be encouraged to foster our understanding of the role of the CFTR in fibroblasts.

\section{Final remarks}

Collectively, the CFTR plays an important role in the regulation of several cellular mechanisms not only in AECs, but also in innate immune cells. CFTR mutations in AECs, neutrophils, monocytes, macrophages and fibroblasts together lead to imbalance of numerous cellular signalling pathways, with negative consequences in several organs. For instance, the accumulation of thick mucus in the lung, leads to colonisation by opportunistic pathogens, such as of $P$. aeruginosa, mainly due to the $\mathrm{Cl}^{-}$and water imbalance [12]. Epithelial cells are then chronically activated, leading to the recruitment of monocytes, macrophages and neutrophils to control the infection (Fig. 1). When these innate immune cells reach the affected site, they take over the inflammatory response leading to an exaggerated and unresolved proinflammatory response. Macrophages fail to destroy most 
of these pathogens, and if the infection is eradicated, these phagocytic cells show a reduced anti-inflammatory reaction, with consequent impaired production of IL-10 (Fig. 2) [27, 172, 199, 209].

Although, a debate still exists as to whether the CFTR is intrinsically proinflammatory or whether it facilitates inflammation indirectly, the fact that inflammation is increased in $\mathrm{CF}$ is unquestionable. HBECs obtained from children with CF less than 5 years old, show significantly higher amounts of IL-8 mRNA when compared with control infants, even in the absence of infections [210]. Several studies support the idea that the defective CFTR facilitates inflammation indirectly, and the exaggerated inflammatory response observed in CF may be due to an exacerbated response to pathogens $[65,210-213]$. In fact, the exaggerated inflammation seen during the pathogenies of CF must be certainly due to a combination of both, the CFTR exerting an intrinsic proinflammatory effect and also due to the vigorous response to microbial infections. The different multi-organ complications in $\mathrm{CF}$ are indeed associated with excessive inflammation, but it remains to be determined how inflammation affects other organs involved in this disease. The recent introduction of new CFTR modulators, such as Trikafta, has proven to be of great benefit to patients with $\mathrm{CF}$; it is of considerable interest to further investigate the effects of these drugs, in different immune cells in the context of CF, and further explore the possibility of testing these drugs in other disorders in order to boost CFTR function.

Acknowledgements The authors thank Mark Kacar for critical reading of the manuscript.

Funding This work was supported by funding from the Cystic Fibrosis Trust (Grant: SRC009) and by the National Council of Science and Technology (CONACyT).

Open Access This article is licensed under a Creative Commons Attribution 4.0 International License, which permits use, sharing, adaptation, distribution and reproduction in any medium or format, as long as you give appropriate credit to the original author(s) and the source, provide a link to the Creative Commons licence, and indicate if changes were made. The images or other third party material in this article are included in the article's Creative Commons licence, unless indicated otherwise in a credit line to the material. If material is not included in the article's Creative Commons licence and your intended use is not permitted by statutory regulation or exceeds the permitted use, you will need to obtain permission directly from the copyright holder. To view a copy of this licence, visit http://creativecommons.org/licenses/by/4.0/.

\section{References}

1. ECFS Patient Registry Annual Data Report (2017) European cystic fibrosis society. https://www.ecfs.eu/sites/default/files/ general-content-images/working-groups/ecfs-patient-registry/ ECFSPR_Report2017_v1.3.pdf. Accessed 21 Oct 2019
2. Patient Registry Annual Data Report (2017) The cystic fibrosis foundation. https://www.cff.org/Research/Researcher-Resources/ Patient-Registry/2017-Patient-Registry-Annual-Data-Report.pdf. Accessed 22 Oct 2019

3. Engelhardt JF, Yankaskas JR, Ernst SA, Yang Y, Marino CR, Boucher RC, Cohn JA, Wilson JM (1992) Submucosal glands are the predominant site of CFTR expression in the human bronchus. Nat Genet 2(3):240-248. https://doi.org/10.1038/ng1192-240

4. Cozens AL, Yezzi MJ, Kunzelmann K, Ohrui T, Chin L, Eng K, Finkbeiner WE, Widdicombe JH, Gruenert DC (1994) CFTR expression and chloride secretion in polarized immortal human bronchial epithelial cells. Am J Respir Cell Mol Biol 10(1):3847. https://doi.org/10.1165/ajrcmb.10.1.7507342

5. Stoltz DA, Rokhlina T, Ernst SE, Pezzulo AA, Ostedgaard LS, Karp PH, Samuel MS, Reznikov LR, Rector MV, Gansemer ND, Bouzek DC, Abou Alaiwa MH, Hoegger MJ, Ludwig PS, Taft PJ, Wallen TJ, Wohlford-Lenane C, McMenimen JD, Chen JH, Bogan KL, Adam RJ, Hornick EE, Nelson GAT, Hoffman EA, Chang EH, Zabner J, McCray PB Jr, Prather RS, Meyerholz DK, Welsh MJ (2013) Intestinal CFTR expression alleviates meconium ileus in cystic fibrosis pigs. J Clin Invest 123(6):26852693. https://doi.org/10.1172/JCI68867

6. Ishiguro H, Steward MC, Naruse S, Ko SB, Goto H, Case RM, Kondo T, Yamamoto A (2009) CFTR functions as a bicarbonate channel in pancreatic duct cells. J Gen Physiol 133(3):315-326. https://doi.org/10.1085/jgp.200810122

7. Tizzano EF, Silver MM, Chitayat D, Benichou JC, Buchwald M (1994) Differential cellular expression of cystic fibrosis transmembrane regulator in human reproductive tissues: clues for the infertility in patients with cystic fibrosis. Am J Pathol 144(5):906-914

8. Patrizio P, Salameh WA (1998) Expression of the cystic fibrosis transmembrane conductance regulator (CFTR) mRNA in normal and pathological adult human epididymis. J Reprod Fertil Suppl 53:261-270

9. Saint-Criq V, Gray MA (2017) Role of CFTR in epithelial physiology. Cell Mol Life Sci 74(1):93-115. https://doi.org/10.1007/ s00018-016-2391-y

10. Lyczak JB, Cannon CL, Pier GB (2002) Lung infections associated with cystic fibrosis. Clin Microbiol Rev 15(2):194-222. https://doi.org/10.1128/cmr.15.2.194-222.2002

11. Clarke EA, Watson P, Freeston JE, Peckham DG, Jones AM, Horsley A (2019) Assessing arthritis in the context of cystic fibrosis. Pediatr Pulmonol 54(6):770-777. https://doi. org/10.1002/ppul.24290

12. Cantin AM, Hartl D, Konstan MW, Chmiel JF (2015) Inflammation in cystic fibrosis lung disease: pathogenesis and therapy. J Cyst Fibros 14(4):419-430. https://doi.org/10.1016/j. jcf.2015.03.003

13. Gibson-Corley KN, Meyerholz DK, Engelhardt JF (2016) Pancreatic pathophysiology in cystic fibrosis. J Pathol 238(2):311320. https://doi.org/10.1002/path.4634

14. Gelfond D, Borowitz D (2013) Gastrointestinal complications of cystic fibrosis. Clin Gastroenterol Hepatol 11(4):333-342. https ://doi.org/10.1016/j.cgh.2012.11.006

15. Kelsey R, Manderson Koivula FN, McClenaghan NH, Kelly C (2019) Cystic fibrosis-related diabetes: pathophysiology and therapeutic challenges. Clin Med Insights Endocrinol Diabetes 12:1179551419851770. https://doi.org/10.1177/1179551419 851770

16. Culhane S, George C, Pearo B, Spoede E (2013) Malnutrition in cystic fibrosis: a review. Nutr Clin Pract 28(6):676-683. https:// doi.org/10.1177/0884533613507086

17. Ahmad A, Ahmed A, Patrizio P (2013) Cystic fibrosis and fertility. Curr Opin Obstet Gynecol 25(3):167-172. https://doi. org/10.1097/GCO.0b013e32835f1745 
18. Edmondson C, Davies JC (2016) Current and future treatment options for cystic fibrosis lung disease: latest evidence and clinical implications. Ther Adv Chronic Dis 7(3):170-183. https:// doi.org/10.1177/2040622316641352

19. Henke MO, Ratjen F (2007) Mucolytics in cystic fibrosis. Paediatr Respir Rev 8(1):24-29. https://doi.org/10.1016/j. prrv.2007.02.009

20. Vertex Pharmaceuticals (2019) Two phase 3 studies of the triple combination of VX-445, tezacaftor and ivacaftor met primary endpoint of improvement in lung function (ppFEV1) in people with cystic fibrosis. https://investors.vrtx.com/news-releases/ news-release-details/correcting-and-replacing-two-phase-3-studi es-triple-combination

21. Ramsey BW, Davies J, McElvaney NG, Tullis E, Bell SC, Drevinek P, Griese M, McKone EF, Wainwright CE, Konstan MW, Moss R, Ratjen F, Sermet-Gaudelus I, Rowe SM, Dong Q, Rodriguez S, Yen K, Ordonez C, Elborn JS, Group VXS (2011) A CFTR potentiator in patients with cystic fibrosis and the G551D mutation. N Engl J Med 365(18):1663-1672. https ://doi.org/10.1056/NEJMoa1105185

22. McDonald TV, Nghiem PT, Gardner P, Martens CL (1992) Human lymphocytes transcribe the cystic fibrosis transmembrane conductance regulator gene and exhibit CFdefective cAMP-regulated chloride current. J Biol Chem 267(5):3242-3248

23. Dong YJ, Chao AC, Kouyama K, Hsu YP, Bocian RC, Moss RB, Gardner P (1995) Activation of CFTR chloride current by nitric oxide in human T lymphocytes. EMBO J 14(12):2700-2707

24. Sturges NC, Wikstrom ME, Winfield KR, Gard SE, Brennan S, Sly PD, Upham JW (2010) Monocytes from children with clinically stable cystic fibrosis show enhanced expression of Toll-like receptor 4. Pediatr Pulmonol 45(9):883-889. https:// doi.org/10.1002/ppul.21230

25. Tarique AA, Sly PD, Cardenas DG, Luo L, Stow JL, Bell SC, Wainwright CE, Fantino E (2019) Differential expression of genes and receptors in monocytes from patients with cystic fibrosis. J Cyst Fibros 18(3):342-348. https://doi.org/10.1016/j. jcf.2018.07.012

26. Tarique AA, Sly PD, Holt PG, Bosco A, Ware RS, Logan J, Bell SC, Wainwright CE, Fantino E (2017) CFTR-dependent defect in alternatively-activated macrophages in cystic fibrosis. J Cyst Fibros 16(4):475-482. https://doi.org/10.1016/j.jcf.2017.03.011

27. Lara-Reyna S, Scambler T, Holbrook J, Wong C, Jarosz-Griffiths HH, Martinon F, Savic S, Peckham D, McDermott MF (2019) Metabolic reprograming of cystic fibrosis macrophages via the IRE1alpha arm of the unfolded protein response results in exacerbated inflammation. Front Immunol 10:1789. https://doi. org/10.3389/fimmu.2019.01789

28. Scambler T, Jarosz-Griffiths HH, Lara-Reyna S, Pathak S, Wong C, Holbrook J, Martinon F, Savic S, Peckham D, McDermott MF (2019) ENaC-mediated sodium influx exacerbates NLRP3dependent inflammation in cystic fibrosis. Elife. https://doi. org/10.7554/eLife.49248

29. Ribeiro CM, Boucher RC (2010) Role of endoplasmic reticulum stress in cystic fibrosis-related airway inflammatory responses. Proc Am Thorac Soc 7(6):387-394. https://doi.org/10.1513/ pats.201001-017AW

30. Ribeiro CMP, Lubamba BA (2017) Role of IRE1 $\alpha / X B P-1$ in cystic fibrosis airway inflammation. Int J Mol Sci 18:1. https:// doi.org/10.3390/ijms18010118

31. Peckham D, Scambler T, Savic S, McDermott MF (2017) The burgeoning field of innate immune-mediated disease and autoinflammation. J Pathol 241(2):123-139. https://doi.org/10.1002/ path. 4812

32. McDermott MF, Aksentijevich I, Galon J, McDermott EM, Ogunkolade BW, Centola M, Mansfield E, Gadina M, Karenko
L, Pettersson T, McCarthy J, Frucht DM, Aringer M, Torosyan Y, Teppo AM, Wilson M, Karaarslan HM, Wan Y, Todd I, Wood G, Schlimgen R, Kumarajeewa TR, Cooper SM, Vella JP, Amos CI, Mulley J, Quane KA, Molloy MG, Ranki A, Powell RJ, Hitman GA, O'Shea JJ, Kastner DL (1999) Germline mutations in the extracellular domains of the $55 \mathrm{kDa}$ TNF receptor, TNFR1, define a family of dominantly inherited autoinflammatory syndromes. Cell 97(1):133-144. https://doi.org/10.1016/s0092 -8674(00)80721-7

33. Manthiram K, Zhou Q, Aksentijevich I, Kastner DL (2017) The monogenic autoinflammatory diseases define new pathways in human innate immunity and inflammation. Nat Immunol 18(8):832-842. https://doi.org/10.1038/ni.3777

34. McGonagle D, McDermott MF (2006) A proposed classification of the immunological diseases. PLoS Med 3(8):e297. https://doi. org/10.1371/journal.pmed.0030297

35. McDermott MF, Aksentijevich I (2002) The autoinflammatory syndromes. Curr Opin Allergy Clin Immunol 2(6):511-516. https ://doi.org/10.1097/00130832-200212000-00006

36. Polverino F, Lu B, Quintero JR, Vargas SO, Patel AS, Owen CA, Gerard NP, Gerard C, Cernadas M (2019) CFTR regulates B cell activation and lymphoid follicle development. Respir Res 20(1):133. https://doi.org/10.1186/s12931-019-1103-1

37. Hector A, Schafer H, Poschel S, Fischer A, Fritzsching B, Ralhan A, Carevic M, Oz H, Zundel S, Hogardt M, Bakele M, Rieber N, Riethmueller J, Graepler-Mainka U, Stahl M, Bender A, Frick JS, Mall M, Hartl D (2015) Regulatory T-cell impairment in cystic fibrosis patients with chronic pseudomonas infection. Am J Respir Crit Care Med 191(8):914-923. https://doi.org/10.1164/ rccm.201407-1381OC

38. Tan HL, Regamey N, Brown S, Bush A, Lloyd CM, Davies JC (2011) The Th17 pathway in cystic fibrosis lung disease. Am J Respir Crit Care Med 184(2):252-258. https://doi.org/10.1164/ rccm.201102-0236OC

39. Ratner D, Mueller C (2012) Immune responses in cystic fibrosis: are they intrinsically defective? Am J Respir Cell Mol Biol 46(6):715-722. https://doi.org/10.1165/rcmb.2011-0399RT

40. Duprez L, Wirawan E, Vanden Berghe T, Vandenabeele P (2009) Major cell death pathways at a glance. Microbes Infect 11(13):1050-1062. https://doi.org/10.1016/j.micinf.2009.08.013

41. Van Opdenbosch N, Lamkanfi M (2019) Caspases in cell death, inflammation, and disease. Immunity 50(6):1352-1364. https:// doi.org/10.1016/j.immuni.2019.05.020

42. Shalini S, Dorstyn L, Dawar S, Kumar S (2015) Old, new and emerging functions of caspases. Cell Death Differ 22(4):526539. https://doi.org/10.1038/cdd.2014.216

43. Vande Walle L, Lamkanfi M (2016) Pyroptosis. Curr Biol 26(13):R568-R572. https://doi.org/10.1016/j.cub.2016.02.019

44. Latz E, Xiao TS, Stutz A (2013) Activation and regulation of the inflammasomes. Nat Rev Immunol 13(6):397-411. https://doi. org/10.1038/nri3452

45. Broz P, Dixit VM (2016) Inflammasomes: mechanism of assembly, regulation and signalling. Nat Rev Immunol 16(7):407-420. https://doi.org/10.1038/nri.2016.58

46. McElvaney OJ, Zaslona Z, Becker-Flegler K, Palsson-McDermott EM, Boland F, Gunaratnam C, Gulbins E, O'Neill LA, Reeves EP, McElvaney NG (2019) Specific inhibition of the NLRP3 inflammasome as an antiinflammatory strategy in cystic fibrosis. Am J Respir Crit Care Med 200(11):1381-1391. https ://doi.org/10.1164/rccm.201905-1013OC

47. Balazs A, Mall MA (2019) Mucus obstruction and inflammation in early cystic fibrosis lung disease: emerging role of the IL-1 signaling pathway. Pediatr Pulmonol 54(Suppl 3):S5-S12. https ://doi.org/10.1002/ppul.24462

48. Iannitti RG, Napolioni V, Oikonomou V, De Luca A, Galosi C, Pariano M, Massi-Benedetti C, Borghi M, Puccetti M, Lucidi V, 
Colombo C, Fiscarelli E, Lass-Florl C, Majo F, Cariani L, Russo M, Porcaro L, Ricciotti G, Ellemunter H, Ratclif L, De Benedictis FM, Talesa VN, Dinarello CA, van de Veerdonk FL, Romani L (2016) IL-1 receptor antagonist ameliorates inflammasomedependent inflammation in murine and human cystic fibrosis. Nat Commun 7:10791. https://doi.org/10.1038/ncomms10791

49. Anderson MP, Gregory RJ, Thompson S, Souza DW, Paul S, Mulligan RC, Smith AE, Welsh MJ (1991) Demonstration that CFTR is a chloride channel by alteration of its anion selectivity. Science 253(5016):202-205. https://doi.org/10.1126/scien ce. 1712984

50. Mall M, Grubb BR, Harkema JR, O'Neal WK, Boucher RC (2004) Increased airway epithelial $\mathrm{Na}+$ absorption produces cystic fibrosis-like lung disease in mice. Nat Med 10(5):487-493. https://doi.org/10.1038/nm1028

51. Hobbs CA, Da Tan C, Tarran R (2013) Does epithelial sodium channel hyperactivity contribute to cystic fibrosis lung disease? J Physiol 591(18):4377-4387. https://doi.org/10.1113/jphys iol.2012.240861

52. Polke M, Seiler F, Lepper PM, Kamyschnikow A, Langer F, Monz D, Herr C, Bals R, Beisswenger C (2017) Hypoxia and the hypoxia-regulated transcription factor HIF-1alpha suppress the host defence of airway epithelial cells. Innate Immun 23(4):373380. https://doi.org/10.1177/1753425917698032

53. Seiler F, Lepper PM, Bals R, Beisswenger C (2014) Regulation and function of antimicrobial peptides in immunity and diseases of the lung. Protein Pept Lett 21(4):341-351. https://doi. org/10.2174/09298665113206660100

54. Beisswenger C, Lysenko ES, Weiser JN (2009) Early bacterial colonization induces toll-like receptor-dependent transforming growth factor beta signaling in the epithelium. Infect Immun 77(5):2212-2220. https://doi.org/10.1128/IAI.01224-08

55. Parker D, Prince A (2011) Type I interferon response to extracellular bacteria in the airway epithelium. Trends Immunol 32(12):582-588. https://doi.org/10.1016/j.it.2011.09.003

56. Pfeifer P, Voss M, Wonnenberg B, Hellberg J, Seiler F, Lepper PM, Bischoff M, Langer F, Schafers HJ, Menger MD, Bals $\mathrm{R}$, Beisswenger C (2013) IL-17C is a mediator of respiratory epithelial innate immune response. Am J Respir Cell Mol Biol 48(4):415-421. https://doi.org/10.1165/rcmb.2012-0232OC

57. Ralhan A, Laval J, Lelis F, Ballbach M, Grund C, Hector A, Hartl D (2016) Current concepts and controversies in innate immunity of cystic fibrosis lung disease. J Innate Immun 8(6):531-540. https://doi.org/10.1159/000446840

58. Estell K, Braunstein G, Tucker T, Varga K, Collawn JF, Schwiebert LM (2003) Plasma membrane CFTR regulates RANTES expression via its C-terminal PDZ-interacting motif. Mol Cell Biol 23(2):594-606. https://doi.org/10.1128/ mcb.23.2.594-606.2003

59. Hallows KR, Fitch AC, Richardson CA, Reynolds PR, Clancy JP, Dagher PC, Witters LA, Kolls JK, Pilewski JM (2006) Up-regulation of AMP-activated kinase by dysfunctional cystic fibrosis transmembrane conductance regulator in cystic fibrosis airway epithelial cells mitigates excessive inflammation. J Biol Chem 281(7):4231-4241. https://doi.org/10.1074/jbc.M511029200

60. Schwiebert LM, Estell K, Propst SM (1999) Chemokine expression in CF epithelia: implications for the role of CFTR in RANTES expression. Am J Physiol 276(3):C700-710. https:// doi.org/10.1152/ajpcell.1999.276.3.C700

61. Rottner M, Kunzelmann C, Mergey M, Freyssinet JM, Martinez MC (2007) Exaggerated apoptosis and NF-kappaB activation in pancreatic and tracheal cystic fibrosis cells. FASEB J 21(11):2939-2948. https://doi.org/10.1096/fj.06-7614com

62. Venkatakrishnan A, Stecenko AA, King G, Blackwell TR, Brigham KL, Christman JW, Blackwell TS (2000) Exaggerated activation of nuclear factor-kappaB and altered IkappaB-beta processing in cystic fibrosis bronchial epithelial cells. Am J Respir Cell Mol Biol 23(3):396-403. https://doi.org/10.1165/ ajrcmb.23.3.3949

63. Zhang YL, Chen PX, Guan WJ, Guo HM, Qiu ZE, Xu JW, Luo YL, Lan CF, Xu JB, Hao Y, Tan YX, Ye KN, Lun ZR, Zhao L, Zhu YX, Huang J, Ko WH, Zhong WD, Zhou WL, Zhong NS (2018) Increased intracellular $\mathrm{Cl}(-)$ concentration promotes ongoing inflammation in airway epithelium. Mucosal Immunol 11(4):1149-1157. https://doi.org/10.1038/s41385-018-0013-8

64. Clauzure M, Valdivieso AG, Massip-Copiz MM, Mori C, Dugour AV, Figueroa JM, Santa-Coloma TA (2017) Intracellular chloride concentration changes modulate IL-1beta expression and secretion in human bronchial epithelial cultured cells. J Cell Biochem 118(8):2131-2140. https://doi.org/10.1002/jcb.25850

65. Aldallal N, McNaughton EE, Manzel LJ, Richards AM, Zabner J, Ferkol TW, Look DC (2002) Inflammatory response in airway epithelial cells isolated from patients with cystic fibrosis. Am J Respir Crit Care Med 166(9):1248-1256. https://doi. org/10.1164/rccm.200206-627OC

66. Pizurki L, Morris MA, Chanson M, Solomon M, Pavirani A, Bouchardy I, Suter S (2000) Cystic fibrosis transmembrane conductance regulator does not affect neutrophil migration across cystic fibrosis airway epithelial monolayers. Am J Pathol 156(4):1407-1416. https://doi.org/10.1016/s0002 -9440(10)65009-2

67. Black HR, Yankaskas JR, Johnson LG, Noah TL (1998) Interleukin-8 production by cystic fibrosis nasal epithelial cells after tumor necrosis factor-alpha and respiratory syncytial virus stimulation. Am J Respir Cell Mol Biol 19(2):210-215. https://doi. org/10.1165/ajrcmb.19.2.3053

68. Becker MN, Sauer MS, Muhlebach MS, Hirsh AJ, Wu Q, Verghese MW, Randell SH (2004) Cytokine secretion by cystic fibrosis airway epithelial cells. Am J Respir Crit Care Med 169(5):645-653. https://doi.org/10.1164/rccm.200207-765OC

69. Riordan JR (2008) CFTR function and prospects for therapy. Annu Rev Biochem 77:701-726. https://doi.org/10.1146/annur ev.biochem.75.103004.142532

70. Li C, Naren AP (2010) CFTR chloride channel in the apical compartments: spatiotemporal coupling to its interacting partners. Integr Biol (Camb) 2(4):161-177. https://doi.org/10.1039/b9244 $55 \mathrm{~g}$

71. Stutts MJ, Canessa CM, Olsen JC, Hamrick M, Cohn JA, Rossier BC, Boucher RC (1995) CFTR as a cAMP-dependent regulator of sodium channels. Science 269(5225):847-850. https://doi. org/10.1126/science. 7543698

72. Stutts MJ, Rossier BC, Boucher RC (1997) Cystic fibrosis transmembrane conductance regulator inverts protein kinase A-mediated regulation of epithelial sodium channel single channel kinetics. J Biol Chem 272(22):14037-14040. https://doi.org/10.1074/ jbc.272.22.14037

73. Katsnelson MA, Rucker LG, Russo HM, Dubyak GR (2015) K+ efflux agonists induce NLRP3 inflammasome activation independently of Ca2+ signaling. J Immunol 194(8):3937-3952. https:// doi.org/10.4049/jimmunol.1402658

74. Keiser NW, Birket SE, Evans IA, Tyler SR, Crooke AK, Sun X, Zhou W, Nellis JR, Stroebele EK, Chu KK, Tearney GJ, Stevens MJ, Harris JK, Rowe SM, Engelhardt JF (2015) Defective innate immunity and hyperinflammation in newborn cystic fibrosis transmembrane conductance regulator-knockout ferret lungs. Am J Respir Cell Mol Biol 52(6):683-694. https://doi. org/10.1165/rcmb.2014-0250OC

75. Fajac I, Viel M, Sublemontier S, Hubert D, Bienvenu T (2008) Could a defective epithelial sodium channel lead to bronchiectasis. Respir Res 9:46. https://doi.org/10.1186/1465-9921-9-46 
76. Franklin BS, Bossaller L, De Nardo D, Ratter JM, Stutz A, Engels G, Brenker C, Nordhoff M, Mirandola SR, Al-Amoudi A, Mangan MS, Zimmer S, Monks BG, Fricke M, Schmidt RE, Espevik T, Jones B, Jarnicki AG, Hansbro PM, Busto P, Marshak-Rothstein A, Hornemann S, Aguzzi A, Kastenmuller W, Latz E (2014) The adaptor ASC has extracellular and 'prionoid' activities that propagate inflammation. Nat Immunol 15(8):727737. https://doi.org/10.1038/ni.2913

77. Fritzsching B, Zhou-Suckow Z, Trojanek JB, Schubert SC, Schatterny J, Hirtz S, Agrawal R, Muley T, Kahn N, Sticht C, Gunkel N, Welte T, Randell SH, Langer F, Schnabel P, Herth FJ, Mall MA (2015) Hypoxic epithelial necrosis triggers neutrophilic inflammation via IL-1 receptor signaling in cystic fibrosis lung disease. Am J Respir Crit Care Med 191(8):902-913. https://doi. org/10.1164/rccm.201409-16100C

78. Gillette DD, Shah PA, Cremer T, Gavrilin MA, Besecker BY, Sarkar A, Knoell DL, Cormet-Boyaka E, Wewers MD, Butchar JP, Tridandapani S (2013) Analysis of human bronchial epithelial cell proinflammatory response to Burkholderia cenocepacia infection: inability to secrete il-1beta. J Biol Chem 288(6):36913695. https://doi.org/10.1074/jbc.C112.430298

79. Klein H, Abu-Arish A, Trinh NT, Luo Y, Wiseman PW, Hanrahan JW, Brochiero E, Sauve R (2016) Investigating CFTR and KCa31 protein/protein interactions. PLoS ONE 11(4):e0153665. https://doi.org/10.1371/journal.pone.0153665

80. Jensen BS, Strobaek D, Christophersen P, Jorgensen TD, Hansen C, Silahtaroglu A, Olesen SP, Ahring PK (1998) Characterization of the cloned human intermediate-conductance $\mathrm{Ca} 2+$-activated $\mathrm{K}+$ channel. Am J Physiol 275(3):C848-856. https://doi. org/10.1152/ajpcell.1998.275.3.C848

81. Vandorpe DH, Shmukler BE, Jiang L, Lim B, Maylie J, Adelman JP, de Franceschi L, Cappellini MD, Brugnara C, Alper SL (1998) cDNA cloning and functional characterization of the mouse $\mathrm{Ca} 2+$-gated $\mathrm{K}+$ channel, mIK1. Roles in regulatory volume decrease and erythroid differentiation. J Biol Chem 273(34):21542-21553. https://doi.org/10.1074/jbc.273.34.21542

82. Moser SL, Harron SA, Crack J, Fawcett JP, Cowley EA (2008) Multiple KCNQ potassium channel subtypes mediate basal anion secretion from the human airway epithelial cell line Calu3. J Membr Biol 221(3):153-163. https://doi.org/10.1007/s0023 2-008-9093-9

83. Philp AR, Riquelme TT, Millar-Buchner P, Gonzalez R, Sepulveda FV, Cid LP, Flores CA (2018) Kcnn4 is a modifier gene of intestinal cystic fibrosis preventing lethality in the Cftr-F508del mouse. Sci Rep 8(1):9320. https://doi.org/10.1038/s41598-01827465-3

84. Bruscia EM, Bonfield TL (2016) Innate and adaptive immunity in cystic fibrosis. Clin Chest Med 37(1):17-29. https://doi. org/10.1016/j.ccm.2015.11.010

85. Xu R, Li C, Wu Y, Shen L, Ma J, Qian J, Ge J (2017) Role of $\mathrm{KCa} 3.1$ channels in macrophage polarization and its relevance in atherosclerotic plaque instability. Arterioscler Thromb Vasc Biol 37(2):226-236. https://doi.org/10.1161/ATVBAHA.116.308461

86. Meyer M, Huaux F, Gavilanes X, van den Brule S, Lebecque P, Lo Re S, Lison D, Scholte B, Wallemacq P, Leal T (2009) Azithromycin reduces exaggerated cytokine production by M1 alveolar macrophages in cystic fibrosis. Am J Respir Cell Mol Biol 41(5):590-602. https://doi.org/10.1165/rcmb.2008-0155O C

87. Balghi H, Robert R, Rappaz B, Zhang X, Wohlhuter-Haddad A, Evagelidis A, Luo Y, Goepp J, Ferraro P, Romeo P, Trebak M, Wiseman PW, Thomas DY, Hanrahan JW (2011) Enhanced $\mathrm{Ca} 2+$ entry due to Orai1 plasma membrane insertion increases IL-8 secretion by cystic fibrosis airways. FASEB J 25(12):42744291. https://doi.org/10.1096/fj.11-187682
88. Duffy SM, Ashmole I, Smallwood DT, Leyland ML, Bradding P (2015) Orai/CRACM1 and KCa3.1 ion channels interact in the human lung mast cell plasma membrane. Cell Commun Signal 13:32. https://doi.org/10.1186/s12964-015-0112-Z

89. Benedetto R, Ousingsawat J, Wanitchakool P, Zhang Y, Holtzman MJ, Amaral M, Rock JR, Schreiber R, Kunzelmann K (2017) Epithelial chloride transport by CFTR requires TMEM16A. Sci Rep 7(1):12397. https://doi.org/10.1038/s41598-017-10910-0

90. Caci E, Scudieri P, Di Carlo E, Morelli P, Bruno S, De Fino I, Bragonzi A, Gianotti A, Sondo E, Ferrera L, Palleschi A, Santambrogio L, Ravazzolo R, Galietta LJ (2015) Upregulation of TMEM16A protein in bronchial epithelial cells by bacterial pyocyanin. PLoS ONE 10(6):e0131775. https://doi.org/10.1371/ journal.pone.0131775

91. Kunzelmann K, Ousingsawat J, Cabrita I, Dousova T, Bahr A, Janda M, Schreiber R, Benedetto R (2019) TMEM16A in cystic fibrosis: activating or inhibiting? Front Pharmacol 10:3. https:// doi.org/10.3389/fphar.2019.00003

92. Veit G, Bossard F, Goepp J, Verkman AS, Galietta LJ, Hanrahan JW, Lukacs GL (2012) Proinflammatory cytokine secretion is suppressed by TMEM16A or CFTR channel activity in human cystic fibrosis bronchial epithelia. Mol Biol Cell 23(21):41884202. https://doi.org/10.1091/mbc.E12-06-0424

93. Sakamoto N, Hayashi S, Gosselink J, Ishii H, Ishimatsu Y, Mukae H, Hogg JC, van Eeden SF (2007) Calcium dependent and independent cytokine synthesis by air pollution particleexposed human bronchial epithelial cells. Toxicol Appl Pharmacol 225(2):134-141. https://doi.org/10.1016/j.taap.2007.07.006

94. Ornatowski W, Poschet JF, Perkett E, Taylor-Cousar JL, Deretic V (2007) Elevated furin levels in human cystic fibrosis cells result in hypersusceptibility to exotoxin A-induced cytotoxicity. J Clin Invest 117(11):3489-3497. https://doi.org/10.1172/JCI31 499

95. Chen Q, Pandi SPS, Kerrigan L, McElvaney NG, Greene CM, Elborn JS, Taggart CC, Weldon S (2018) Cystic fibrosis epithelial cells are primed for apoptosis as a result of increased Fas (CD95). J Cyst Fibros 17(5):616-623. https://doi.org/10.1016/j. jcf.2018.01.010

96. Bajmoczi M, Gadjeva M, Alper SL, Pier GB, Golan DE (2009) Cystic fibrosis transmembrane conductance regulator and caveolin-1 regulate epithelial cell internalization of Pseudomonas aeruginosa. Am J Physiol Cell Physiol 297(2):C263-277. https ://doi.org/10.1152/ajpcell.00527.2008

97. Pier GB, Grout M, Zaidi TS (1997) Cystic fibrosis transmembrane conductance regulator is an epithelial cell receptor for clearance of Pseudomonas aeruginosa from the lung. Proc Natl Acad Sci USA 94(22):12088-12093. https://doi.org/10.1073/ pnas.94.22.12088

98. Raoust E, Balloy V, Garcia-Verdugo I, Touqui L, Ramphal R, Chignard M (2009) Pseudomonas aeruginosa LPS or flagellin are sufficient to activate TLR-dependent signaling in murine alveolar macrophages and airway epithelial cells. PLoS ONE 4(10):e7259. https://doi.org/10.1371/journal.pone.0007259

99. Blohmke CJ, Park J, Hirschfeld AF, Victor RE, Schneiderman J, Stefanowicz D, Chilvers MA, Durie PR, Corey M, Zielenski J, Dorfman R, Sandford AJ, Daley D, Turvey SE (2010) TLR5 as an anti-inflammatory target and modifier gene in cystic fibrosis. J Immunol 185(12):7731-7738. https://doi.org/10.4049/jimmu nol.1001513

100. John G, Yildirim AO, Rubin BK, Gruenert DC, Henke MO (2010) TLR-4-mediated innate immunity is reduced in cystic fibrosis airway cells. Am J Respir Cell Mol Biol 42(4):424-431. https://doi.org/10.1165/rcmb.2008-0408OC

101. Kelly C, Canning P, Buchanan PJ, Williams MT, Brown V, Gruenert DC, Elborn JS, Ennis M, Schock BC (2013) Tolllike receptor 4 is not targeted to the lysosome in cystic fibrosis 
airway epithelial cells. Am J Physiol Lung Cell Mol Physiol 304(5):L371-382. https://doi.org/10.1152/ajplung.00372.2011

102. Bruscia EM, Zhang PX, Satoh A, Caputo C, Medzhitov R, Shenoy A, Egan ME, Krause DS (2011) Abnormal trafficking and degradation of TLR4 underlie the elevated inflammatory response in cystic fibrosis. J Immunol 186(12):6990-6998. https ://doi.org/10.4049/jimmunol.1100396

103. Chaudhary N, Datta K, Askin FB, Staab JF, Marr KA (2012) Cystic fibrosis transmembrane conductance regulator regulates epithelial cell response to Aspergillus and resultant pulmonary inflammation. Am J Respir Crit Care Med 185(3):301-310. https ://doi.org/10.1164/rccm.201106-1027OC

104. Chen F, Zhang C, Jia X, Wang S, Wang J, Chen Y, Zhao J, Tian S, Han X, Han L (2015) Transcriptome profiles of human lung epithelial cells A549 interacting with Aspergillus fumigatus by RNA-Seq. PLoS ONE 10(8):e0135720. https://doi.org/10.1371/ journal.pone. 0135720

105. Botterel F, Gross K, Ibrahim-Granet O, Khoufache K, Escabasse V, Coste A, Cordonnier C, Escudier E, Bretagne S (2008) Phagocytosis of Aspergillus fumigatus conidia by primary nasal epithelial cells in vitro. BMC Microbiol 8:97. https://doi. org/10.1186/1471-2180-8-97

106. Hamon Y, Jaillon S, Person C, Ginies JL, Garo E, Bottazzi B, Ghamrawi S, Urban T, Subra JF, Bouchara JP, Mantovani A, Jeannin P, Delneste Y (2013) Proteolytic cleavage of the long pentraxin PTX3 in the airways of cystic fibrosis patients. Innate Immun 19(6):611-622. https://doi.org/10.1177/1753425913 476741

107. Moalli F, Doni A, Deban L, Zelante T, Zagarella S, Bottazzi B, Romani L, Mantovani A, Garlanda C (2010) Role of complement and $\mathrm{Fc}\{$ gamma $\}$ receptors in the protective activity of the long pentraxin PTX3 against Aspergillus fumigatus. Blood 116(24):5170-5180. https://doi.org/10.1182/blood-2009-12258376

108. Heltshe SL, Mayer-Hamblett N, Burns JL, Khan U, Baines A, Ramsey BW, Rowe SM (2015) Pseudomonas aeruginosa in cystic fibrosis patients with G551D-CFTR treated with ivacaftor. Clin Infect Dis 60(5):703-712. https://doi.org/10.1093/cid/ciu94 4

109. Ley K, Hoffman HM, Kubes P, Cassatella MA, Zychlinsky A, Hedrick CC, Catz SD (2018) Neutrophils: new insights and open questions. Sci Immunol 3(30):1. https://doi.org/10.1126/sciim munol.aat4579

110. Cowland JB, Borregaard N (2016) Granulopoiesis and granules of human neutrophils. Immunol Rev 273(1):11-28. https://doi. org/10.1111/imr.12440

111. Lee WL, Harrison RE, Grinstein S (2003) Phagocytosis by neutrophils. Microbes Infect 5(14):1299-1306. https://doi. org/10.1016/j.micinf.2003.09.014

112. Hsu MJ, Lee SS, Lee ST, Lin WW (2003) Signaling mechanisms of enhanced neutrophil phagocytosis and chemotaxis by the polysaccharide purified from Ganoderma lucidum. Br J Pharmacol 139(2):289-298. https://doi.org/10.1038/sj.bjp.0705243

113. van Kessel KP, Bestebroer J, van Strijp JA (2014) Neutrophilmediated phagocytosis of Staphylococcus aureus. Front Immunol 5:467. https://doi.org/10.3389/fimmu.2014.00467

114. Khan MA, Farahvash A, Douda DN, Licht JC, Grasemann H, Sweezey N, Palaniyar N (2017) JNK activation turns on LPSand Gram-negative bacteria-induced NADPH oxidase-dependent suicidal NETosis. Sci Rep 7(1):3409. https://doi.org/10.1038/ s41598-017-03257-z

115. Brinkmann V, Zychlinsky A (2007) Beneficial suicide: why neutrophils die to make NETs. Nat Rev Microbiol 5(8):577-582. https://doi.org/10.1038/nrmicro1710

116. Tamassia N, Bianchetto-Aguilera F, Arruda-Silva F, Gardiman E, Gasperini S, Calzetti F, Cassatella MA (2018) Cytokine production by human neutrophils: revisiting the "dark side of the moon". Eur J Clin Invest 48:e12952. https://doi.org/10.1111/ eci. 12952

117. Tecchio C, Micheletti A, Cassatella MA (2014) Neutrophilderived cytokines: facts beyond expression. Front Immunol 5:508. https://doi.org/10.3389/fimmu.2014.00508

118. Adib-Conquy M, Pedron T, Petit-Bertron AF, Tabary O, Corvol H, Jacquot J, Clement A, Cavaillon JM (2008) Neutrophils in cystic fibrosis display a distinct gene expression pattern. Mol Med 14(1-2):36-44. https://doi.org/10.2119/2007-00081.AdibConquy

119. Rada B (2017) Interactions between neutrophils and Pseudomonas aeruginosa in cystic fibrosis. Pathogens 6(1):1. https ://doi.org/10.3390/pathogens6010010

120. Young RL, Malcolm KC, Kret JE, Caceres SM, Poch KR, Nichols DP, Taylor-Cousar JL, Saavedra MT, Randell SH, Vasil ML, Burns JL, Moskowitz SM, Nick JA (2011) Neutrophil extracellular trap (NET)-mediated killing of Pseudomonas aeruginosa: evidence of acquired resistance within the CF airway, independent of CFTR. PLoS ONE 6(9):e23637. https://doi.org/10.1371/ journal.pone. 0023637

121. Herzog S, Dach F, de Buhr N, Niemann S, Schlagowski J, Chaves-Moreno D, Neumann C, Goretzko J, Schwierzeck V, Mellmann A, Dubbers A, Kuster P, Schultingkemper H, Rescher U, Pieper DH, von Kockritz-Blickwede M, Kahl BC (2019) High nuclease activity of long persisting Staphylococcus aureus isolates within the airways of cystic fibrosis patients protects against NET-mediated killing. Front Immunol 10:2552. https:// doi.org/10.3389/fimmu.2019.02552

122. Coburn B, Wang PW, Diaz Caballero J, Clark ST, Brahma V, Donaldson S, Zhang Y, Surendra A, Gong Y, Elizabeth Tullis D, Yau YC, Waters VJ, Hwang DM, Guttman DS (2015) Lung microbiota across age and disease stage in cystic fibrosis. Sci Rep 5:10241. https://doi.org/10.1038/srep10241

123. Painter RG, Valentine VG, Lanson NA Jr, Leidal K, Zhang Q, Lombard G, Thompson C, Viswanathan A, Nauseef WM, Wang G, Wang G (2006) CFTR expression in human neutrophils and the phagolysosomal chlorination defect in cystic fibrosis. Biochemistry 45(34):10260-10269. https://doi.org/10.1021/bi060 $490 \mathrm{t}$

124. Zhou Y, Song K, Painter RG, Aiken M, Reiser J, Stanton BA, Nauseef WM, Wang G (2013) Cystic fibrosis transmembrane conductance regulator recruitment to phagosomes in neutrophils. J Innate Immun 5(3):219-230. https://doi.org/10.1159/00034 6568

125. Chapman AL, Hampton MB, Senthilmohan R, Winterbourn CC, Kettle AJ (2002) Chlorination of bacterial and neutrophil proteins during phagocytosis and killing of Staphylococcus aureus. J Biol Chem 277(12):9757-9762. https://doi.org/10.1074/jbc. M106134200

126. Dickerhof N, Isles V, Pattemore P, Hampton MB, Kettle AJ (2019) Exposure of Pseudomonas aeruginosa to bactericidal hypochlorous acid during neutrophil phagocytosis is compromised in cystic fibrosis. J Biol Chem 294(36):13502-13514. https://doi.org/10.1074/jbc.RA119.009934

127. Robledo-Avila FH, Ruiz-Rosado JD, Brockman KL, Kopp BT, Amer AO, McCoy K, Bakaletz LO, Partida-Sanchez S (2018) Dysregulated calcium homeostasis in cystic fibrosis neutrophils leads to deficient antimicrobial responses. J Immunol 201(7):2016-2027. https://doi.org/10.4049/jimmunol.1800076

128. Leuer L, Krill A, Wilkens H, Wagenpfeil G, Bischoff M, Meier C, Bals R, Tschernig T (2019) The phagocytosis of blood leukocytes from cystic fibrosis patients is not impaired in general. Lung 198(1):235-239. https://doi.org/10.1007/s00408-01900290-9 
129. Bratcher PE, Rowe SM, Reeves G, Roberts T, Szul T, Harris WT, Tirouvanziam R, Gaggar A (2016) Alterations in blood leukocytes of G551D-bearing cystic fibrosis patients undergoing treatment with ivacaftor. J Cyst Fibros 15(1):67-73. https://doi. org/10.1016/j.jcf.2015.02.010

130. Rosenjack J, Hodges CA, Darrah RJ, Kelley TJ (2019) HDAC6 depletion improves cystic fibrosis mouse airway responses to bacterial challenge. Sci Rep 9(1):10282. https://doi.org/10.1038/ s41598-019-46555-4

131. Branzk N, Papayannopoulos V (2013) Molecular mechanisms regulating NETosis in infection and disease. Semin Immunopathol 35(4):513-530. https://doi.org/10.1007/s0028 1-013-0384-6

132. Marcos V, Zhou-Suckow Z, Onder Yildirim A, Bohla A, Hector A, Vitkov L, Krautgartner WD, Stoiber W, Griese M, Eickelberg O, Mall MA, Hartl D (2015) Free DNA in cystic fibrosis airway fluids correlates with airflow obstruction. Mediat Inflamm 2015:408935. https://doi.org/10.1155/2015/408935

133. Kirchner KK, Wagener JS, Khan TZ, Copenhaver SC, Accurso FJ (1996) Increased DNA levels in bronchoalveolar lavage fluid obtained from infants with cystic fibrosis. Am J Respir Crit Care Med 154(5):1426-1429. https://doi.org/10.1164/ajrcc m.154.5.8912759

134. Hovold G, Palmcrantz V, Kahn F, Egesten A, Pahlman LI (2018) Heparin-binding protein in sputum as a marker of pulmonary inflammation, lung function, and bacterial load in children with cystic fibrosis. BMC Pulm Med 18(1):104. https://doi. org/10.1186/s12890-018-0668-7

135. Dwyer M, Shan Q, D'Ortona S, Maurer R, Mitchell R, Olesen H, Thiel S, Huebner J, Gadjeva M (2014) Cystic fibrosis sputum DNA has NETosis characteristics and neutrophil extracellular trap release is regulated by macrophage migration-inhibitory factor. J Innate Immun 6(6):765-779. https://doi.org/10.1159/00036 3242

136. Sagel SD, Sontag MK, Wagener JS, Kapsner RK, Osberg I, Accurso FJ (2002) Induced sputum inflammatory measures correlate with lung function in children with cystic fibrosis. J Pediatr 141(6):811-817. https://doi.org/10.1067/mpd.2002.129847

137. Sagel SD, Kapsner R, Osberg I, Sontag MK, Accurso FJ (2001) Airway inflammation in children with cystic fibrosis and healthy children assessed by sputum induction. Am J Respir Crit Care Med 164(8 Pt 1):1425-1431. https://doi.org/10.1164/ajrcc m.164.8.2104075

138. Papayannopoulos V, Staab D, Zychlinsky A (2011) Neutrophil elastase enhances sputum solubilization in cystic fibrosis patients receiving DNase therapy. PLoS ONE 6(12):e28526. https://doi. org/10.1371/journal.pone.0028526

139. Yoo DG, Floyd M, Winn M, Moskowitz SM, Rada B (2014) NET formation induced by Pseudomonas aeruginosa cystic fibrosis isolates measured as release of myeloperoxidase-DNA and neutrophil elastase-DNA complexes. Immunol Lett 160(2):186-194. https://doi.org/10.1016/j.imlet.2014.03.003

140. Chandler JD, Margaroli C, Horati H, Kilgore MB, Veltman M, Liu HK, Taurone AJ, Peng L, Guglani L, Uppal K, Go YM, Tiddens H, Scholte BJ, Tirouvanziam R, Jones DP, Janssens HM (2018) Myeloperoxidase oxidation of methionine associates with early cystic fibrosis lung disease. Eur Respir J 52(4):1. https:// doi.org/10.1183/13993003.01118-2018

141. Dittrich AS, Kuhbandner I, Gehrig S, Rickert-Zacharias V, Twigg M, Wege S, Taggart CC, Herth F, Schultz C, Mall MA (2018) Elastase activity on sputum neutrophils correlates with severity of lung disease in cystic fibrosis. Eur Respir J 51:3. https ://doi.org/10.1183/13993003.01910-2017

142. Karandashova S, Kummarapurugu A, Zheng S, Kang L, Sun S, Rubin BK, Voynow JA (2018) Neutrophil elastase correlates with increased sphingolipid content in cystic fibrosis sputum. Pediatr Pulmonol 53(7):872-880. https://doi.org/10.1002/ppul.24001

143. Oriano M, Terranova L, Sotgiu G, Saderi L, Bellofiore A, Retucci M, Marotta C, Gramegna A, Miglietta D, Carnini C, Marchisio P, Chalmers JD, Aliberti S, Blasi F (2019) Evaluation of active neutrophil elastase in sputum of bronchiectasis and cystic fibrosis patients: a comparison among different techniques. Pulm Pharmacol Ther 59:101856. https://doi.org/10.1016/j. pupt.2019.101856

144. Taggart C, Coakley RJ, Greally P, Canny G, O’Neill SJ, McElvaney NG (2000) Increased elastase release by CF neutrophils is mediated by tumor necrosis factor-alpha and interleukin-8. Am J Physiol Lung Cell Mol Physiol 278(1):L33-41. https://doi. org/10.1152/ajplung.2000.278.1.L33

145. Forrest OA, Chopyk DM, Gernez Y, Brown MR, Conrad CK, Moss RB, Tangpricha V, Peng L, Tirouvanziam R (2019) Resistin is elevated in cystic fibrosis sputum and correlates negatively with lung function. J Cyst Fibros 18(1):64-70. https://doi. org/10.1016/j.jcf.2018.05.018

146. Margaroli C, Garratt LW, Horati H, Dittrich AS, Rosenow T, Montgomery ST, Frey DL, Brown MR, Schultz C, Guglani L, Kicic A, Peng L, Scholte BJ, Mall MA, Janssens HM, Stick SM, Tirouvanziam R (2019) Elastase exocytosis by airway neutrophils is associated with early lung damage in children with cystic fibrosis. Am J Respir Crit Care Med 199(7):873-881. https://doi. org/10.1164/rccm.201803-0442OC

147. Quinn RA, Adem S, Mills RH, Comstock W, DeRight GL, Humphrey G, Aksenov AA, Melnik AV, da Silva R, Ackermann G, Bandeira N, Gonzalez DJ, Conrad D, O'Donoghue AJ, Knight R, Dorrestein PC (2019) Neutrophilic proteolysis in the cystic fibrosis lung correlates with a pathogenic microbiome. Microbiome 7(1):23. https://doi.org/10.1186/s40168-019-0636-3

148. Rahman S, Gadjeva M (2014) Does NETosis contribute to the bacterial pathoadaptation in cystic fibrosis? Front Immunol 5:378. https://doi.org/10.3389/fimmu.2014.00378

149. Sly PD, Gangell CL, Chen L, Ware RS, Ranganathan S, Mott LS, Murray CP, Stick SM, Investigators AC (2013) Risk factors for bronchiectasis in children with cystic fibrosis. N Engl J Med 368(21):1963-1970. https://doi.org/10.1056/NEJMoa1301725

150. Rosenow T, Mok LC, Turkovic L, Berry LJ, Sly PD, Ranganathan S, Tiddens H, Stick SM (2019) The cumulative effect of inflammation and infection on structural lung disease in early cystic fibrosis. Eur Respir J 54(1):1. https://doi.org/10.1183/13993 003.01771-2018

151. Davies G, Thia LP, Stocks J, Bush A, Hoo AF, Wade A, Nguyen TTD, Brody AS, Calder A, Klein NJ, Carr SB, Wallis C, Suri R, Pao CS, Ruiz G, Balfour-Lynn IM, London Cystic Fibrosis C (2020) Minimal change in structural, functional and inflammatory markers of lung disease in newborn screened infants with cystic fibrosis at one year. J Cyst Fibros. https://doi.org/10.1016/j. jcf.2020.01.006

152. Skopelja S, Hamilton BJ, Jones JD, Yang ML, Mamula M, Ashare A, Gifford AH, Rigby WF (2016) The role for neutrophil extracellular traps in cystic fibrosis autoimmunity. JCI Insight 1(17):e88912. https://doi.org/10.1172/jci.insight.88912

153. Yadav R, Yoo DG, Kahlenberg JM, Bridges SL Jr, Oni O, Huang H, Stecenko A, Rada B (2019) Systemic levels of anti-PAD4 autoantibodies correlate with airway obstruction in cystic fibrosis. J Cyst Fibros 18(5):636-645. https://doi.org/10.1016/j. jcf.2018.12.010

154. Gray RD, Hardisty G, Regan KH, Smith M, Robb CT, Duffin R, Mackellar A, Felton JM, Paemka L, McCullagh BN, Lucas CD, Dorward DA, McKone EF, Cooke G, Donnelly SC, Singh PK, Stoltz DA, Haslett C, McCray PB, Whyte MKB, Rossi AG, Davidson DJ (2018) Delayed neutrophil apoptosis enhances NET 
formation in cystic fibrosis. Thorax 73(2):134-144. https://doi. org/10.1136/thoraxjnl-2017-210134

155. Pohl K, Hayes E, Keenan J, Henry M, Meleady P, Molloy K, Jundi B, Bergin DA, McCarthy C, McElvaney OJ, White MM, Clynes M, Reeves EP, McElvaney NG (2014) A neutrophil intrinsic impairment affecting Rab27a and degranulation in cystic fibrosis is corrected by CFTR potentiator therapy. Blood 124(7):999-1009. https://doi.org/10.1182/blood-2014-02-55526 8

156. Dubois AV, Gauthier A, Brea D, Varaigne F, Diot P, Gauthier F, Attucci S (2012) Influence of DNA on the activities and inhibition of neutrophil serine proteases in cystic fibrosis sputum. Am J Respir Cell Mol Biol 47(1):80-86. https://doi.org/10.1165/ rcmb.2011-0380OC

157. Kanik ET, Yilmaz O, Ozdogru E, Alper H, Ulman C, Kanik A, Simsek Y, Yuksel H (2020) Relevance between clinical status and exhaled molecules related to neutrophilic inflammation in pediatric cystic fibrosis. J Breath Res. https://doi. org/10.1088/1752-7163/ab670d

158. Le Gars M, Descamps D, Roussel D, Saussereau E, Guillot L, Ruffin M, Tabary O, Hong SS, Boulanger P, Paulais M, Malleret L, Belaaouaj A, Edelman A, Huerre M, Chignard M, Sallenave JM (2013) Neutrophil elastase degrades cystic fibrosis transmembrane conductance regulator via calpains and disables channel function in vitro and in vivo. Am J Respir Crit Care Med 187(2):170-179. https://doi.org/10.1164/rccm.201205-0875OC

159. Keir HR, Fong CJ, Crichton ML, Barth P, Chevalier E, Brady G, Kennedy G, Zimmermann J, Bruijnzeel PLB, Dicker AJ, Chalmers JD (2019) Personalised anti-inflammatory therapy for bronchiectasis and cystic fibrosis: selecting patients for controlled trials of neutrophil elastase inhibition. ERJ Open Res 5(1):1. https://doi.org/10.1183/23120541.00252-2018

160. Watz H, Nagelschmitz J, Kirsten A, Pedersen F, van der Mey D, Schwers S, Bandel TJ, Rabe KF (2019) Safety and efficacy of the human neutrophil elastase inhibitor BAY 85-8501 for the treatment of non-cystic fibrosis bronchiectasis: a randomized controlled trial. Pulm Pharmacol Ther 56:86-93. https://doi. org/10.1016/j.pupt.2019.03.009

161. Bardin P, Foussigniere T, Rousselet N, Rebeyrol C, Porter JC, Corvol H, Tabary O (2019) miR-636: a newly-identified actor for the regulation of pulmonary inflammation in cystic fibrosis. Front Immunol 10:2643. https://doi.org/10.3389/fimmu.2019.02643

162. Makam M, Diaz D, Laval J, Gernez Y, Conrad CK, Dunn CE, Davies ZA, Moss RB, Herzenberg LA, Herzenberg LA, Tirouvanziam R (2009) Activation of critical, host-induced, metabolic and stress pathways marks neutrophil entry into cystic fibrosis lungs. Proc Natl Acad Sci USA 106(14):5779-5783. https://doi. org/10.1073/pnas.0813410106

163. Carevic M, Singh A, Rieber N, Eickmeier O, Griese M, Hector A, Hartl D (2015) CXCR4+ granulocytes reflect fungal cystic fibrosis lung disease. Eur Respir J 46(2):395-404. https://doi. org/10.1183/09031936.00173514

164. Hartl D, Latzin P, Hordijk P, Marcos V, Rudolph C, Woischnik M, Krauss-Etschmann S, Koller B, Reinhardt D, Roscher AA, Roos D, Griese M (2007) Cleavage of CXCR1 on neutrophils disables bacterial killing in cystic fibrosis lung disease. Nat Med 13(12):1423-1430. https://doi.org/10.1038/nm1690

165. Houston N, Stewart N, Smith DS, Bell SC, Champion AC, Reid DW (2013) Sputum neutrophils in cystic fibrosis patients display a reduced respiratory burst. J Cyst Fibros 12(4):352-362. https:// doi.org/10.1016/j.jcf.2012.11.004

166. Castellani S, D’Oria S, Diana A, Polizzi AM, Di Gioia S, Mariggio MA, Guerra L, Favia M, Vinella A, Leonetti G, De Venuto D, Gallo C, Montemurro P, Conese M (2019) G-CSF and GM-CSF modify neutrophil functions at concentrations found in cystic fibrosis. Sci Rep 9(1):12937. https://doi.org/10.1038/s4159 8-019-49419-z

167. Turnbull AR, Pyle CJ, Patel DF, Jackson PL, Hilliard TN, Regamey N, Tan HL, Brown S, Thursfield R, Short C, Mc Fie M, Alton E, Gaggar A, Blalock JE, Lloyd CM, Bush A, Davies JC, Snelgrove RJ (2020) Abnormal pro-gly-pro pathway and airway neutrophilia in pediatric cystic fibrosis. J Cyst Fibros 19(1):40-48. https://doi.org/10.1016/j.jcf.2019.05.017

168. Bonfield TL, Hodges CA, Cotton CU, Drumm ML (2012) Absence of the cystic fibrosis transmembrane regulator (Cftr) from myeloid-derived cells slows resolution of inflammation and infection. J Leukoc Biol 92(5):1111-1122. https://doi. org/10.1189/jlb.0412188

169. Zaman MM, Gelrud A, Junaidi O, Regan MM, Warny M, Shea JC, Kelly C, O'Sullivan BP, Freedman SD (2004) Interleukin 8 secretion from monocytes of subjects heterozygous for the deltaF508 cystic fibrosis transmembrane conductance regulator gene mutation is altered. Clin Diagn Lab Immunol 11(5):819-824. https://doi.org/10.1128/CDLI.11.5.819-824.2004

170. Alexis NE, Muhlebach MS, Peden DB, Noah TL (2006) Attenuation of host defense function of lung phagocytes in young cystic fibrosis patients. J Cyst Fibros 5(1):17-25. https://doi. org/10.1016/j.jcf.2005.11.001

171. Rao S, Wright AK, Montiero W, Ziegler-Heitbrock L, Grigg J (2009) Monocyte chemoattractant chemokines in cystic fibrosis. J Cyst Fibros 8(2):97-103. https://doi.org/10.1016/j. jcf.2008.09.009

172. Zhang S, Shrestha CL, Kopp BT (2018) Cystic fibrosis transmembrane conductance regulator (CFTR) modulators have differential effects on cystic fibrosis macrophage function. Sci Rep 8(1):17066. https://doi.org/10.1038/s41598-018-35151-7

173. Hisert KB, Schoenfelt KQ, Cooke G, Grogan B, Launspach JL, Gallagher CG, Donnelly SC, Welsh MJ, Singh PK, McKone EF, Becker L (2016) Ivacaftor-induced proteomic changes suggest monocyte defects may contribute to the pathogenesis of cystic fibrosis. Am J Respir Cell Mol Biol 54(4):594-597. https://doi. org/10.1165/rcmb.2015-0322LE

174. Velard F, Jourdain ML, Abdallah D, Jacquot J, Ronan N, McCarthy Y, Flanagan E, Plant B (2018) Overexpression of RANK and M-CSFR in Monocytes of G551D-Bearing Patients with Cystic Fibrosis. Am J Respir Crit Care Med 198(7):968-970. https:// doi.org/10.1164/rccm.201803-0415LE

175. Scambler T, Holbrook J, Savic S, McDermott MF, Peckham D (2018) Autoinflammatory disease in the lung. Immunology. https ://doi.org/10.1111/imm.12937

176. Savic S, Caseley EA, McDermott MF (2020) Moving towards a systems-based classification of innate immune-mediated diseases. Nat Rev Rheumatol. https://doi.org/10.1038/s4158 4-020-0377-5

177. Jarosz-Griffiths HH, Scambler T, Wong CH, Lara-Reyna S, Holbrook J, Martinon F, Savic S, Whitaker P, Etherington C, Spoletini G, Clifton I, Mehta A, McDermott MF, Peckham D (2020) Different CFTR modulator combinations downregulate inflammation differently in cystic fibrosis. Elife. https://doi. org/10.7554/eLife.54556

178. McKiernan PJ, Molloy KP, Cryan SA, McElvaney NG, Greene CM (2018) X chromosome-encoded MicroRNAs are functionally increased in cystic fibrosis monocytes. Am J Respir Crit Care Med 197(5):668-670. https://doi.org/10.1164/rccm.20170 7-1417LE

179. Zhang X, Pan A, Jia S, Ideozu JE, Woods K, Murkowski K, Hessner MJ, Simpson PM, Levy H (2019) Cystic Fibrosis Plasma Blunts the Immune Response to Bacterial Infection. Am J Respir Cell Mol Biol 61(3):301-311. https://doi.org/10.1165/ rcmb.2018-0114OC 
180. Kopp BT, Fitch J, Jaramillo L, Shrestha CL, Robledo-Avila F, Zhang S, Palacios S, Woodley F, Hayes D Jr, Partida-Sanchez S, Ramilo O, White P, Mejias A (2019) Whole-blood transcriptomic responses to lumacaftor/ivacaftor therapy in cystic fibrosis. J Cyst Fibros. https://doi.org/10.1016/j.jcf.2019.08.021

181. Averna M, Bavestrello M, Cresta F, Pedrazzi M, De Tullio R, Minicucci L, Sparatore B, Salamino F, Pontremoli S, Melloni E (2016) Abnormal activation of calpain and protein kinase Calpha promotes a constitutive release of matrix metalloproteinase 9 in peripheral blood mononuclear cells from cystic fibrosis patients. Arch Biochem Biophys 604:103-112. https://doi.org/10.1016/j. abb.2016.06.015

182. Avendano-Ortiz J, Llanos-Gonzalez E, Toledano V, Del Campo R, Cubillos-Zapata C, Lozano-Rodriguez R, Ismail A, Prados C, Gomez-Campelo P, Aguirre LA, Garcia-Rio F, Lopez-Collazo E (2019) Pseudomonas aeruginosa colonization causes PD-L1 overexpression on monocytes, impairing the adaptive immune response in patients with cystic fibrosis. J Cyst Fibros 18(5):630 635. https://doi.org/10.1016/j.jcf.2018.11.002

183. Shapouri-Moghaddam A, Mohammadian S, Vazini H, Taghadosi M, Esmaeili SA, Mardani F, Seifi B, Mohammadi A, Afshari JT, Sahebkar A (2018) Macrophage plasticity, polarization, and function in health and disease. J Cell Physiol 233(9):6425-6440. https://doi.org/10.1002/jcp.26429

184. Arango Duque G, Descoteaux A (2014) Macrophage cytokines: involvement in immunity and infectious diseases. Front Immunol 5:491. https://doi.org/10.3389/fimmu.2014.00491

185. Italiani P, Boraschi D (2014) From monocytes to M1/M2 macrophages: phenotypical vs functional differentiation. Front Immunol 5:514. https://doi.org/10.3389/fimmu.2014.00514

186. Murray PJ, Allen JE, Biswas SK, Fisher EA, Gilroy DW, Goerdt S, Gordon S, Hamilton JA, Ivashkiv LB, Lawrence T, Locati M, Mantovani A, Martinez FO, Mege JL, Mosser DM, Natoli G, Saeij JP, Schultze JL, Shirey KA, Sica A, Suttles J, Udalova I, van Ginderachter JA, Vogel SN, Wynn TA (2014) Macrophage activation and polarization: nomenclature and experimental guidelines. Immunity 41(1):14-20. https://doi.org/10.1016/j. immuni.2014.06.008

187. Leveque M, Le Trionnaire S, Del Porto P, Martin-Chouly C (2017) The impact of impaired macrophage functions in cystic fibrosis disease progression. J Cyst Fibros 16(4):443-453. https ://doi.org/10.1016/j.jcf.2016.10.011

188. Davies LC, Jenkins SJ, Allen JE, Taylor PR (2013) Tissue-resident macrophages. Nat Immunol 14(10):986-995. https://doi. org/10.1038/ni.2705

189. Lubamba BA, Jones LC, O’Neal WK, Boucher RC, Ribeiro CM (2015) X-box-binding protein 1 and innate immune responses of human cystic fibrosis alveolar macrophages. Am J Respir Crit Care Med 192(12):1449-1461. https://doi.org/10.1164/ rccm.201504-0657OC

190. Hubeau C, Puchelle E, Gaillard D (2001) Distinct pattern of immune cell population in the lung of human fetuses with cystic fibrosis. J Allergy Clin Immunol 108(4):524-529. https://doi. org/10.1067/mai.2001.118516

191. Brennan S, Sly PD, Gangell CL, Sturges N, Winfield K, Wikstrom M, Gard S, Upham JW, Arest CF (2009) Alveolar macrophages and $\mathrm{CC}$ chemokines are increased in children with cystic fibrosis. Eur Respir J 34(3):655-661. https://doi. org/10.1183/09031936.00178508

192. Bonfield TL, Panuska JR, Konstan MW, Hilliard KA, Hilliard JB, Ghnaim H, Berger M (1995) Inflammatory cytokines in cystic fibrosis lungs. Am J Respir Crit Care Med 152(6 Pt 1):21112118. https://doi.org/10.1164/ajrccm.152.6.8520783
193. Bardon A (1987) Cystic fibrosis. Carbohydrate metabolism in $\mathrm{CF}$ and in animal models for CF. Acta Paediatr Scand Suppl 332:1-30

194. O'Rawe A (1992) Energy metabolism in cystic fibrosis. Proc Nutr Soc 51(2):237-244. https://doi.org/10.1079/pns19920034

195. Dickie LJ, Aziz AM, Savic S, Lucherini OM, Cantarini L, Geiler J, Wong CH, Coughlan R, Lane T, Lachmann HJ, Hawkins PN, Robinson PA, Emery P, McGonagle D, McDermott MF (2012) Involvement of $\mathrm{X}$-box binding protein 1 and reactive oxygen species pathways in the pathogenesis of tumour necrosis factor receptor-associated periodic syndrome. Ann Rheum Dis 71(12):2035-2043. https://doi.org/10.1136/annrheumdis-2011201197

196. Salzano S, Checconi P, Hanschmann EM, Lillig CH, Bowler LD, Chan P, Vaudry D, Mengozzi M, Coppo L, Sacre S, Atkuri KR, Sahaf B, Herzenberg LA, Herzenberg LA, Mullen L, Ghezzi P (2014) Linkage of inflammation and oxidative stress via release of glutathionylated peroxiredoxin-2, which acts as a danger signal. Proc Natl Acad Sci USA 111(33):12157-12162. https://doi. org/10.1073/pnas.1401712111

197. De Cauwer A, Mariotte A, Sibilia J, Bahram S, Georgel P (2018) DICER 1: a key player in rheumatoid arthritis, at the crossroads of cellular stress, innate immunity, and chronic inflammation in aging. Front Immunol 9:1647. https://doi.org/10.3389/fimmu 2018.01647

198. Bornfeldt KE, Tabas I (2011) Insulin resistance, hyperglycemia, and atherosclerosis. Cell Metab 14(5):575-585. https://doi. org/10.1016/j.cmet.2011.07.015

199. Simonin-Le Jeune K, Le Jeune A, Jouneau S, Belleguic C, Roux PF, Jaguin M, Dimanche-Boitre MT, Lecureur V, Leclercq C, Desrues B, Brinchault G, Gangneux JP, Martin-Chouly C (2013) Impaired functions of macrophage from cystic fibrosis patients: CD11b, TLR-5 decrease and sCD14, inflammatory cytokines increase. PLoS ONE 8(9):e75667. https://doi.org/10.1371/journ al.pone.0075667

200. Porto PD, Cifani N, Guarnieri S, Di Domenico EG, Mariggiò MA, Spadaro F, Guglietta S, Anile M, Venuta F, Quattrucci S, Ascenzioni F (2011) Dysfunctional CFTR alters the bactericidal activity of human macrophages against Pseudomonas aeruginosa. PLoS ONE 6:5. https://doi.org/10.1371/journal.pone.00199 70

201. Descamps D, Le Gars M, Balloy V, Barbier D, Maschalidi S, Tohme M, Chignard M, Ramphal R, Manoury B, Sallenave JM (2012) Toll-like receptor 5 (TLR5), IL-1beta secretion, and asparagine endopeptidase are critical factors for alveolar macrophage phagocytosis and bacterial killing. Proc Natl Acad Sci USA 109(5):1619-1624. https://doi.org/10.1073/pnas.11084 64109

202. O'Neill LAJ, Artyomov MN (2019) Itaconate: the poster child of metabolic reprogramming in macrophage function. Nat Rev Immunol 19(5):273-281. https://doi.org/10.1038/s4157 7-019-0128-5

203. Lampropoulou V, Sergushichev A, Bambouskova M, Nair S, Vincent EE, Loginicheva E, Cervantes-Barragan L, Ma X, Huang SC, Griss T, Weinheimer CJ, Khader S, Randolph GJ, Pearce EJ, Jones RG, Diwan A, Diamond MS, Artyomov MN (2016) Itaconate links inhibition of succinate dehydrogenase with macrophage metabolic remodeling and regulation of inflammation. Cell Metab 24(1):158-166. https://doi.org/10.1016/j. cmet.2016.06.004

204. Mills EL, Ryan DG, Prag HA, Dikovskaya D, Menon D, Zaslona Z, Jedrychowski MP, Costa ASH, Higgins M, Hams E, Szpyt J, Runtsch MC, King MS, McGouran JF, Fischer R, Kessler BM, McGettrick AF, Hughes MM, Carroll RG, Booty LM, Knatko EV, Meakin PJ, Ashford MLJ, Modis LK, Brunori G, Sevin DC, 
Fallon PG, Caldwell ST, Kunji ERS, Chouchani ET, Frezza C, Dinkova-Kostova AT, Hartley RC, Murphy MP, O’Neill LA (2018) Itaconate is an anti-inflammatory metabolite that activates Nrf2 via alkylation of KEAP1. Nature 556(7699):113-117. https ://doi.org/10.1038/nature25986

205. Van Linthout S, Miteva K, Tschope C (2014) Crosstalk between fibroblasts and inflammatory cells. Cardiovasc Res 102(2):258269. https://doi.org/10.1093/cvr/cvu062

206. Flavell SJ, Hou TZ, Lax S, Filer AD, Salmon M, Buckley CD (2008) Fibroblasts as novel therapeutic targets in chronic inflammation. Br J Pharmacol 153(Suppl 1):S241-246. https://doi. org/10.1038/sj.bjp.0707487

207. Yoshimura K, Nakamura H, Trapnell BC, Chu CS, Dalemans W, Pavirani A, Lecocq JP, Crystal RG (1991) Expression of the cystic fibrosis transmembrane conductance regulator gene in cells of non-epithelial origin. Nucleic Acids Res 19(19):54175423. https://doi.org/10.1093/nar/19.19.5417

208. Huaux F, Noel S, Dhooghe B, Panin N, Lo Re S, Lison D, Wallemacq P, Marbaix E, Scholte BJ, Lebecque P, Leal T (2013) Dysregulated proinflammatory and fibrogenic phenotype of fibroblasts in cystic fibrosis. PLoS ONE 8(5):e64341. https:// doi.org/10.1371/journal.pone.0064341

209. Ulrich M, Worlitzsch D, Viglio S, Siegmann N, Iadarola P, Shute JK, Geiser M, Pier GB, Friedel G, Barr ML, Schuster A, Meyer KC, Ratjen F, Bjarnsholt T, Gulbins E, Doring G (2010) Alveolar inflammation in cystic fibrosis. J Cyst Fibros 9(3):217-227. https ://doi.org/10.1016/j.jcf.2010.03.001

210. Muhlebach MS, Stewart PW, Leigh MW, Noah TL (1999) Quantitation of inflammatory responses to bacteria in young cystic fibrosis and control patients. Am J Respir Crit Care Med 160(1):186-191. https://doi.org/10.1164/ajrccm.160.1.9808096

211. Khan TZ, Wagener JS, Bost T, Martinez J, Accurso FJ, Riches DW (1995) Early pulmonary inflammation in infants with cystic fibrosis. Am J Respir Crit Care Med 151(4):1075-1082. https:// doi.org/10.1164/ajrccm/151.4.1075

212. Heeckeren A, Walenga R, Konstan MW, Bonfield T, Davis PB, Ferkol T (1997) Excessive inflammatory response of cystic fibrosis mice to bronchopulmonary infection with Pseudomonas aeruginosa. J Clin Invest 100(11):2810-2815. https://doi. org/10.1172/jci119828

213. Sutanto EN, Kicic A, Foo CJ, Stevens PT, Mullane D, Knight DA, Stick SM (2011) Innate inflammatory responses of pediatric cystic fibrosis airway epithelial cells: effects of nonviral and viral stimulation. Am J Respir Cell Mol Biol 44(6):761-767. https:// doi.org/10.1165/rcmb.2010-0368OC

214. De Boeck K, Amaral MD (2016) Progress in therapies for cystic fibrosis. Lancet Respir Med 4(8):662-674. https://doi. org/10.1016/S2213-2600(16)00023-0

215. Marson FAL, Bertuzzo CS, Ribeiro JD (2016) Classification of CFTR mutation classes. Lancet Respir Med 4(8):e37-e38. https ://doi.org/10.1016/S2213-2600(16)30188-6

Publisher's Note Springer Nature remains neutral with regard to jurisdictional claims in published maps and institutional affiliations. 